\title{
WestVirginiaUniversity
}

THE RESEARCH REPOSITORY @ WVU

Graduate Theses, Dissertations, and Problem Reports

2011

\section{Identification of design guidelines for a mobile oncology unit}

\author{
Renee Melendez Thompson
}

West Virginia University

Follow this and additional works at: https://researchrepository.wvu.edu/etd

\section{Recommended Citation}

Thompson, Renee Melendez, "Identification of design guidelines for a mobile oncology unit" (2011). Graduate Theses, Dissertations, and Problem Reports. 3296.

https://researchrepository.wvu.edu/etd/3296

This Thesis is protected by copyright and/or related rights. It has been brought to you by the The Research Repository @ WVU with permission from the rights-holder(s). You are free to use this Thesis in any way that is permitted by the copyright and related rights legislation that applies to your use. For other uses you must obtain permission from the rights-holder(s) directly, unless additional rights are indicated by a Creative Commons license in the record and/ or on the work itself. This Thesis has been accepted for inclusion in WVU Graduate Theses, Dissertations, and Problem Reports collection by an authorized administrator of The Research Repository @ WVU. For more information, please contact researchrepository@mail.wvu.edu. 
By Renee Melendez Thompson

Thesis submitted to the

Davis College of Agriculture, Natural Resources, and Design

at West Virginia University

in partial fulfillment of the requirements

for the degree of

Master of Science

in

Design \& Merchandising

with a Certificate in Health Care Administration

Barbara McFall, PhD, Chair

Cindy Beacham, PhD

Nancy Adams, PhD

Division of Design \& Merchandising

Morgantown, West Virginia

2011

Keywords: Mobile Oncology Units, Cancer Treatment Centers, Health Care Design, Interior Design, Rural West Virginia, Health Care Services, Healing Environments Copyright 2011 Renee Melendez Thompson 


\title{
ABSTRACT \\ DESIGN CONSIDERATIONS FOR MOBILE ONCOLOGY UNITS
}

\author{
Renee Melendez Thompson
}

This thesis will identify design considerations for future development of a mobile unit for delivery of Oncology services to those engaged directly or indirectly in cancer treatment. Mobile Oncology Units are relatively new to medical and design worlds but offer benefits as extensions of the healthcare system that provide care to those who would not normally receive it. This project targets rural communities, the elderly and those without transportation in West Virginia. 


\section{DEDICATION}

I dedicate this thesis to my loving and supportive husband Bradley who encouraged me throughout my entire education and motivated me to follow through on everything I set out to accomplish. His persistence gave me the strength and confidence necessary to push forward when I encountered challenges. I do not know what I would do without his presence in my life. 


\section{ACKNOWLEDGEMENTS}

It is my pleasure to thank those who made this thesis possible by providing guidance, advice, and remaining faithful in my perseverance.

My utmost gratitude belongs to Barbara McFall Ph.D., director of the Division of Design and Merchandising of West Virginia University. Acting supervisor, advisor, and committee chair, Dr. McFall has led me through obstacles, nurtured educational and personal growth, and remained unwavering for completion of this thesis.

I would also like to convey my sincere appreciation towards committee member and undergraduate professor, Cindy Beacham Ph.D., who mentored and inspired many facets of my life.

I am very thankful to committee member and graduate professor Nancy Adams, Ph.D., whose experience in the medical field proved an invaluable asset to my education.

My education would not of have been made possible without the, behind the scenes, efforts of staff and student advisor of the Division of Design and Merchandising, Joy Patterson.

I would like to thank my parents James and Lois Topper for their continual support in all ventures throughout my life and their encouragement of pursuing happiness.

I would also like to thank my sister Suzy, brother Christopher, and the rest of my family and friends who continually encouraged and influence all aspects of my life. 


\section{TABLE OF CONTENTS}

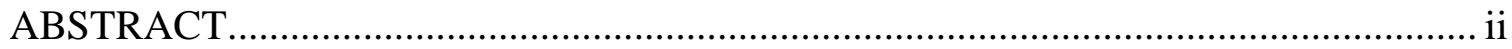

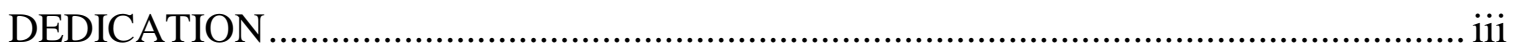

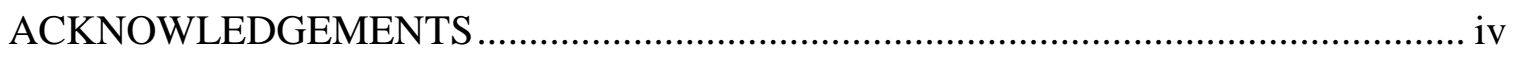

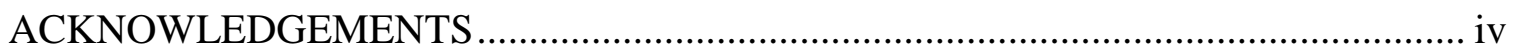

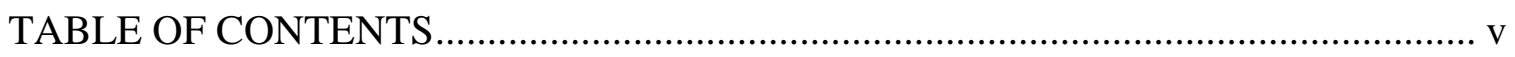

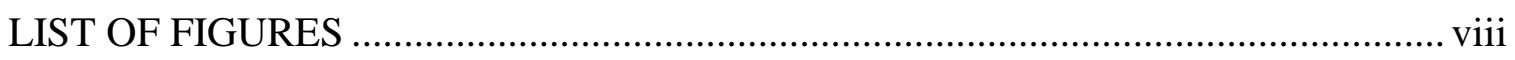

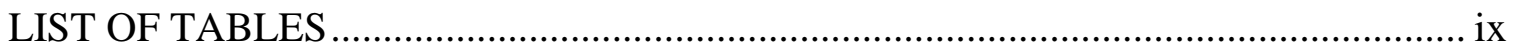

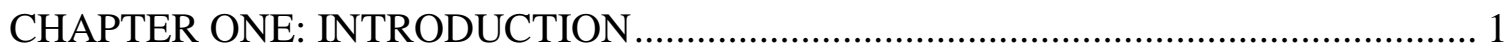

Mobile Oncology Units ..................................................................................... 1

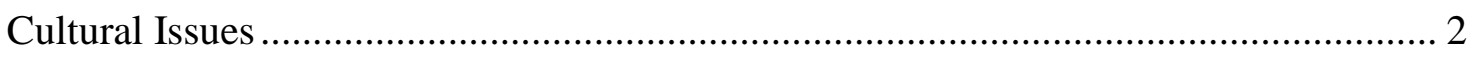

Population Density and Rural Health Services......................................................... 2

Age

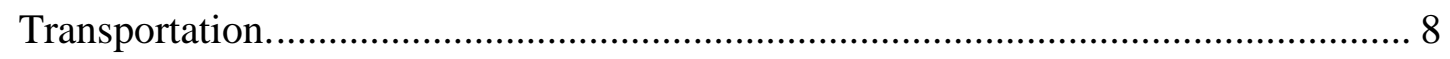

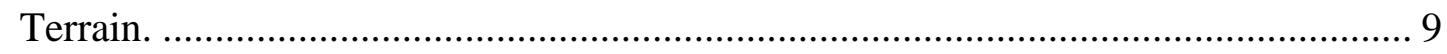

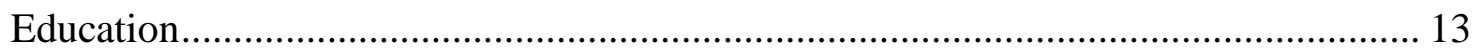

CHAPTER TWO: LITERATURE REVIEW ………………………………............ 14

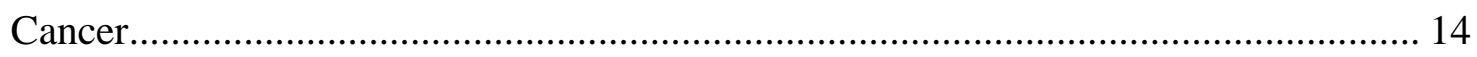

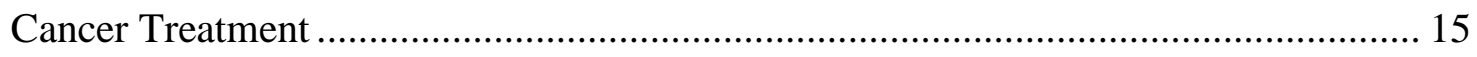

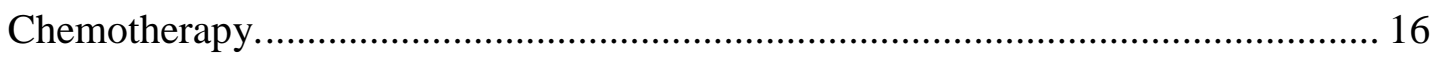

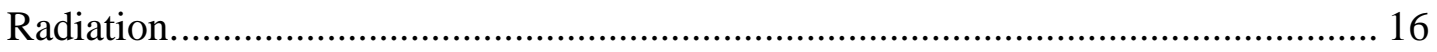

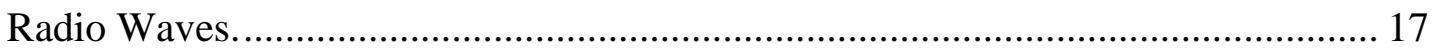

Alternative/Complementary Options.................................................................... 17

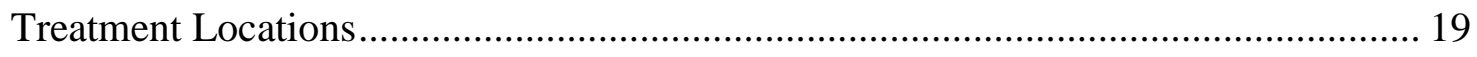


Design as a Research Guideline ......................................................................... 26

Design Process as a Methodology ................................................................. 28

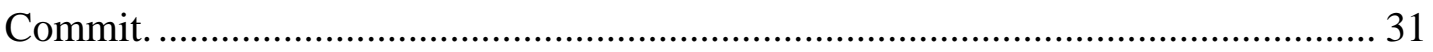

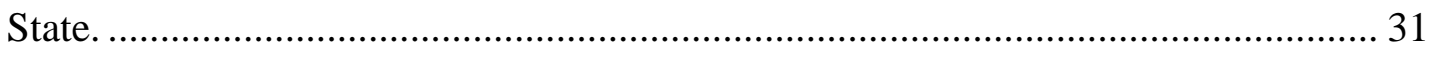

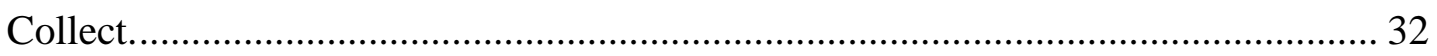

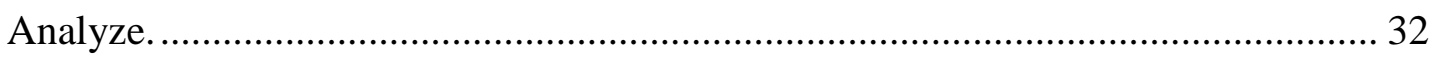

Evidence-based Design as a Resource .............................................................. 32

Design Process with Evidence-Based Data........................................................... 33

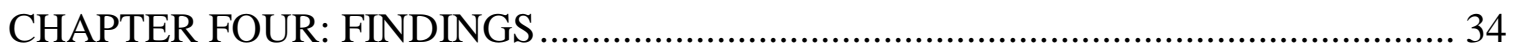

Mobile Unit ...................................................................................................... 34

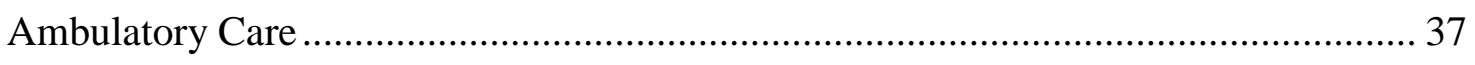

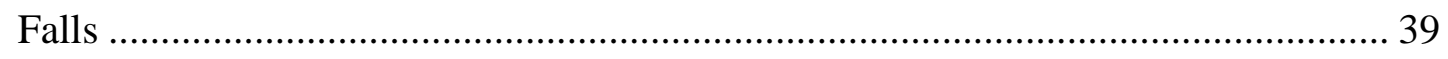

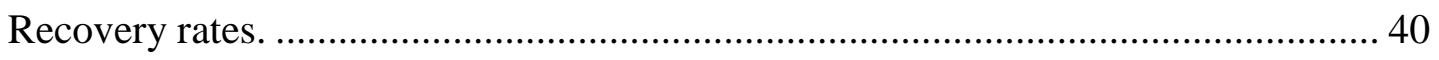

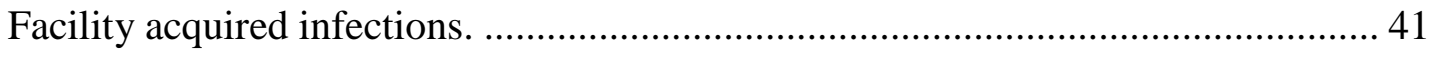

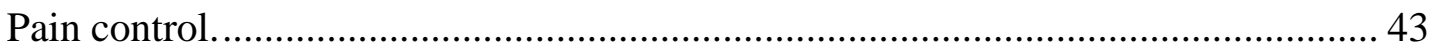

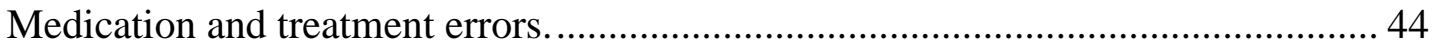

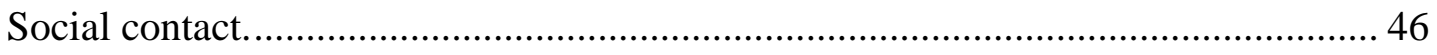

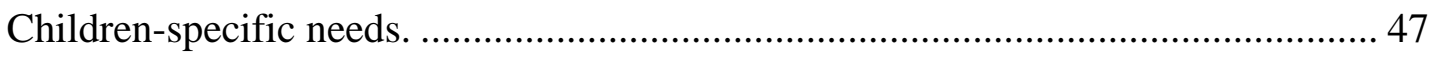

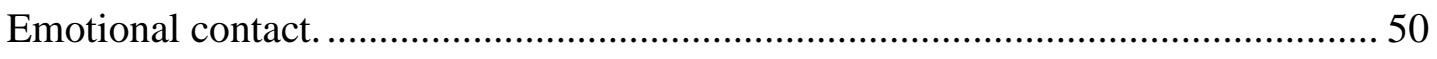

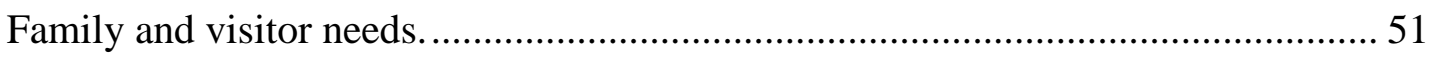

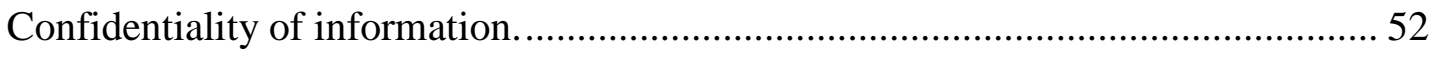

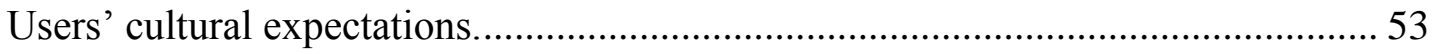

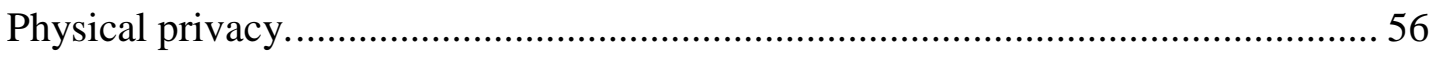


Disabled needs.

Staff member needs.

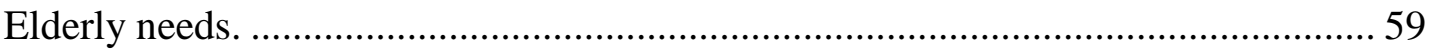

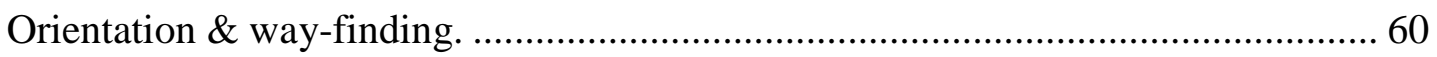

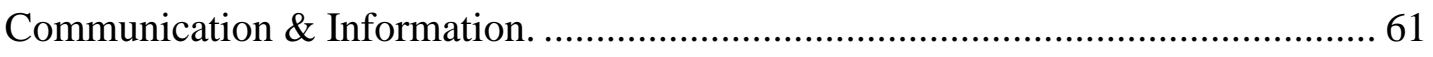

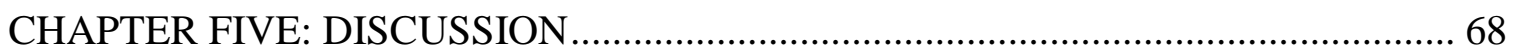

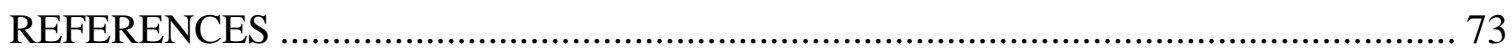




\section{LIST OF FIGURES}

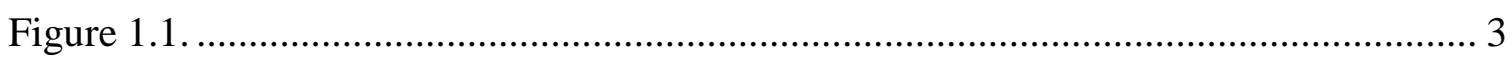

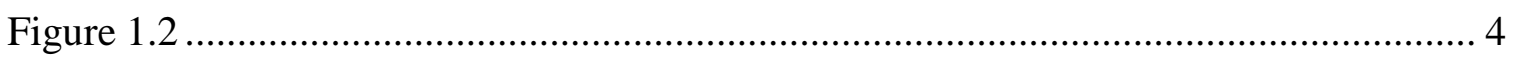

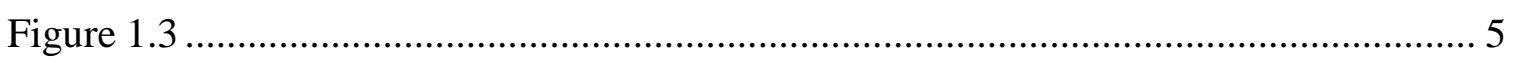

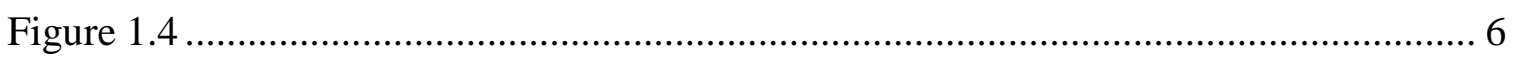

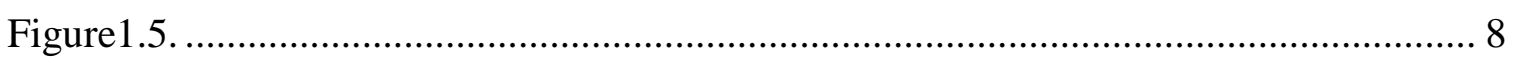

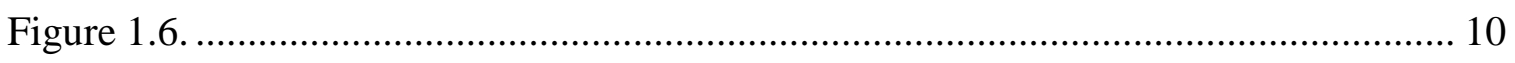

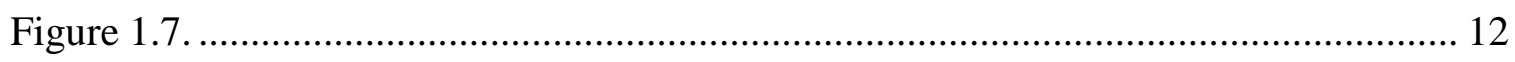

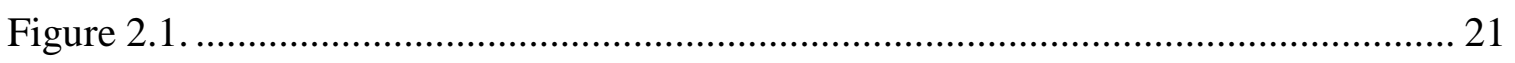

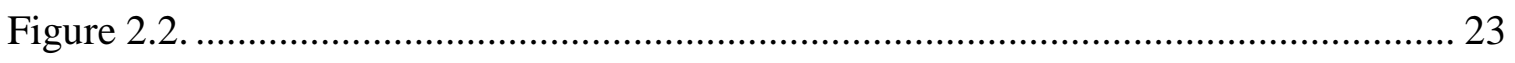

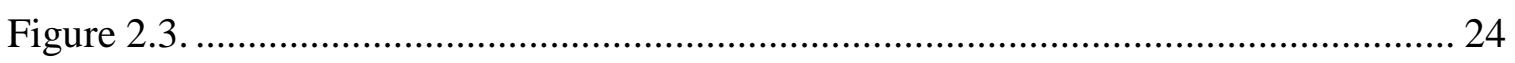

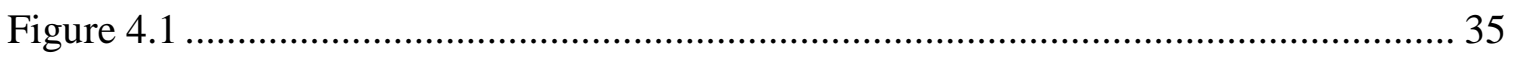

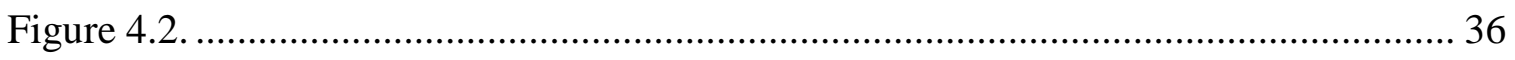

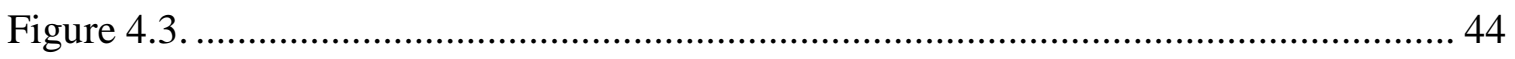

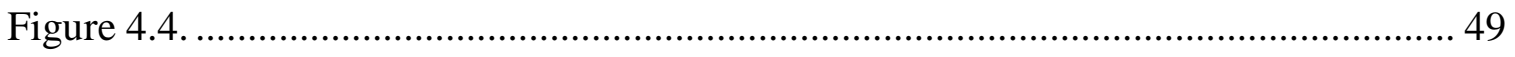




\section{LIST OF TABLES}

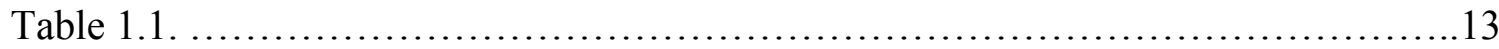

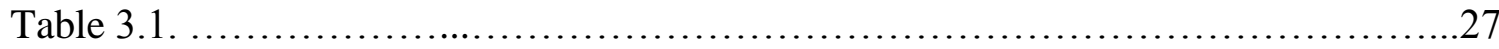

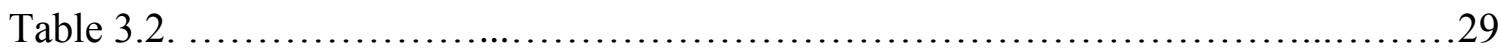

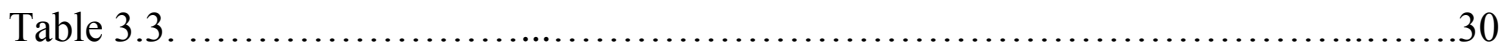

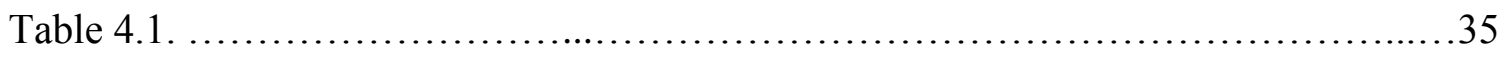

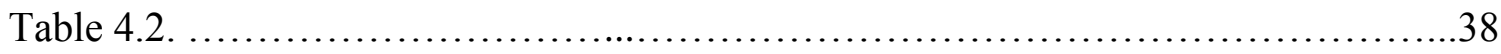

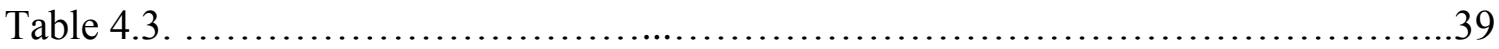

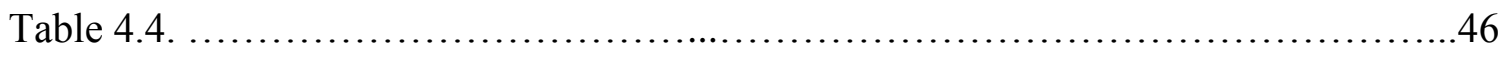

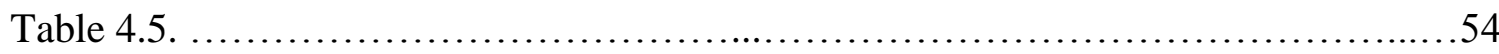

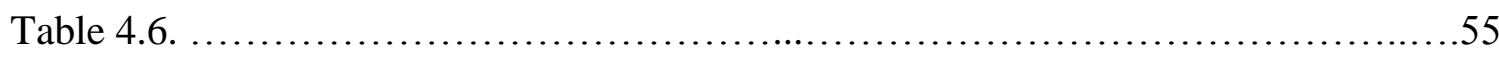

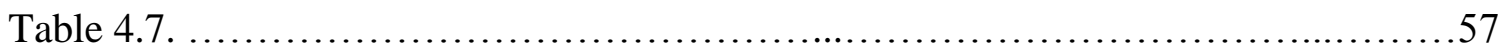

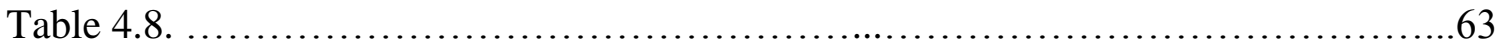

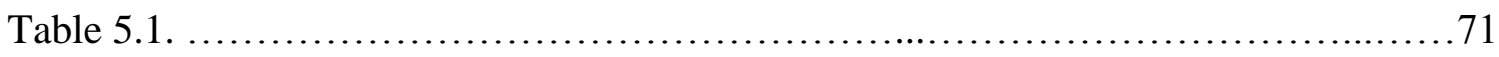




\section{CHAPTER ONE: INTRODUCTION}

\section{Overview}

This thesis provides design guidelines for a prototype mobile unit for delivery of services related to the cancer treatment for populations in rural West Virginia. Cancer is the second largest cause of death in the state of West Virginia. It was responsible for eight percent of all West Virginia deaths for the period 1995-2005 (“Cancer Death Rate Down for First Time," 2008). Cancer treatments currently involve chemotherapy, radiation, and complementary therapy. Historically treatment has been delivered in a medical facility or within the confines of a hospital. More recently, free standing outpatient facilities have been designed and built to move healthcare closer to the users and make it more readily accessible to patients. Though outpatient facilities fulfill their purpose well for urban patients, healthcare services have not yet fully reached the larger population of rural communities and the elderly due to issues with transportation, terrain and financial logistics. Advances in medical research are lost without efficient, effective application. This paper investigates efficient and effective small space, mobile solutions through design to improve the quality of living of users.

\section{Mobile Oncology Units}

Mobile Oncology Units expand upon the transportation-based protocol perfected by blood bank units, clinical units, breast cancer evaluation units, etc. Mobile units will be able to provide the same services as an outpatient center while bringing the care to the patient. According to the American Cancer Society, infusion centers are "special areas within the medical oncology department for administering intravenous chemotherapy to patients who are not admitted for an overnight stay in the hospital.” (American Cancer 
Society [ACS], 2011). The design of these units will allow appropriately trained medical staff to administer chemotherapy, a variety of alternative therapies and counseling sessions. Staff will also be tasked to conduct support groups, facilitate guidance and provide information, friendship, and comfort to the patients and families. Small mobile spaces are capable of supporting a healing environment through the use of the design process and evidence-based design as resources. These units are ideal for rural areas that have difficult cultural barriers like West Virginia. Examples of cultural barriers include but not limited to access issues, smaller communities, older population, mountainous terrain, lack of transportation, etc.

\section{Cultural Issues}

Population Density and Rural Health Services. The economics of high population density, and the accessibility afforded by good roads in close proximity, facilitate healthcare by providing information, services and treatment to the public in metropolitan and suburban areas. Lacking such advantages, West Virginia's rural communities often fail to receive proper attention. The census shows that $55.1 \%$ of West Virginians reside in metropolitan areas (large cities), 19.9\% live in suburban areas (smaller residential communities lying immediately outside a city), and 25\% inhabit rural areas (an area outside of cities and towns) (Miller, K., 2006; see Figure 1.1). This indicates that although half of the population resides in or near a city/town, over half of the state is still geographically rural. 


\section{Population Density, 2000}

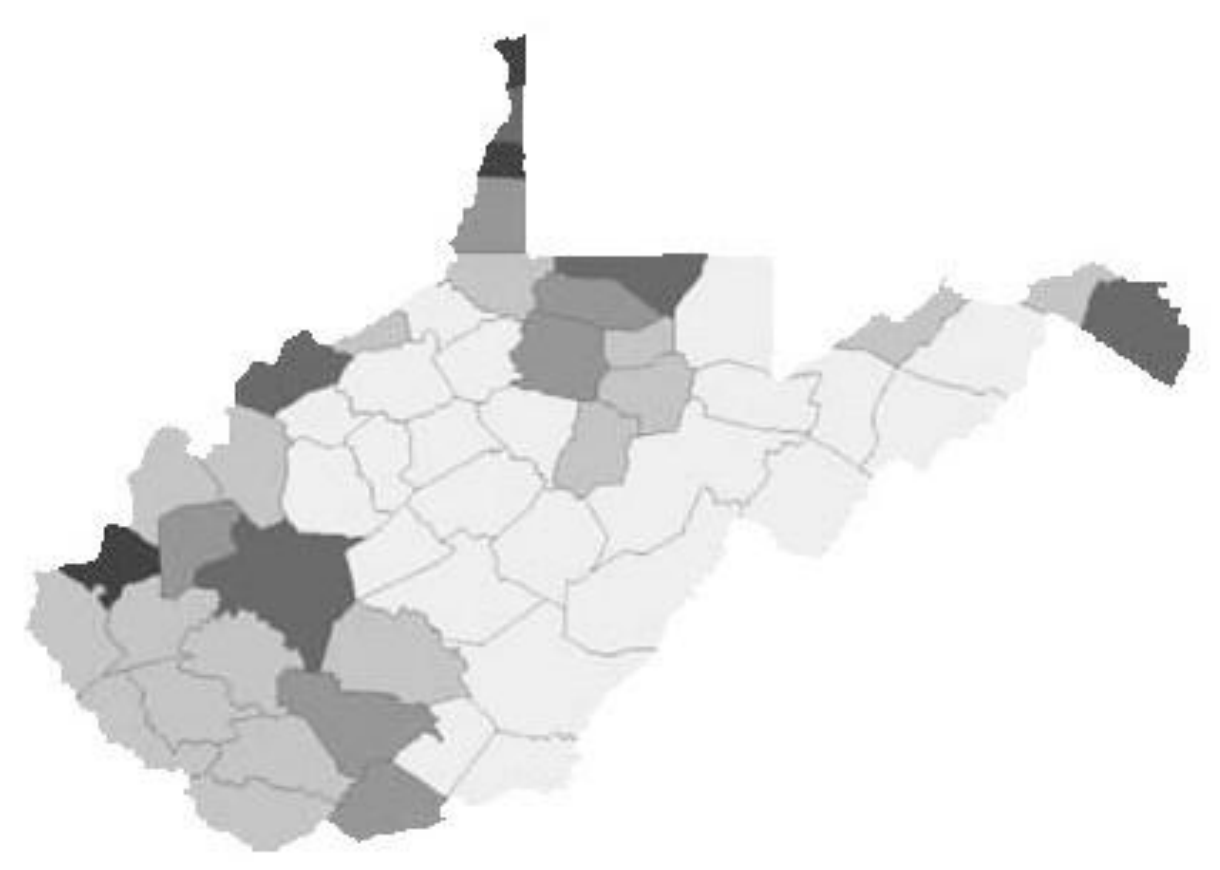

People Per Square Mile

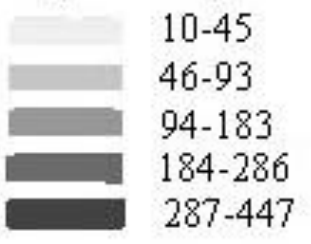

$10-45$

$46-93$

$94-183$

184-286

$287-447$

0

45

90

180

Miles

Figure 1.1. West Virginia's population density map depicts the number of people that live per square mile by county in the state. Those counties that are the darkest have the largest concentration of people and generally indicate locations of metropolitan cities. Adapted from "United States Census 2000" by U.S. Census Bureau, 2000, Census 2000 data for the state of West Virginia. Copyright 2000 by U.S. Census Bureau.

Of the fifty-five counties of West Virginia, only twenty-one counties are considered metropolitan (see Figure 1.2). Examples of metropolitan areas in West Virginia are Charleston, Morgantown, Huntington-Ashland, Parkersburg-Marietta- 
Vienna, Weirton-Steubenville, and Wheeling. Examples of suburban areas in West

Virginia are Cassville, Westover, Brookhaven, Pleasant Valley, Mannington, Kingwood,

Despard, Stonewood, Grafton, Marmet, and Point Pleasant. Areas considered rural are

Masontown, Hundred, Pine Grove, Tunnelton, West Milford, Whitehall, Mill Creek,

Monongah, Elizabeth, Davis, and Cedar Grove ("West Virginia Very Small Towns and

Villages (fewer than 10000 residents)," 2009). Those underserved rural communities are the target population of this thesis.

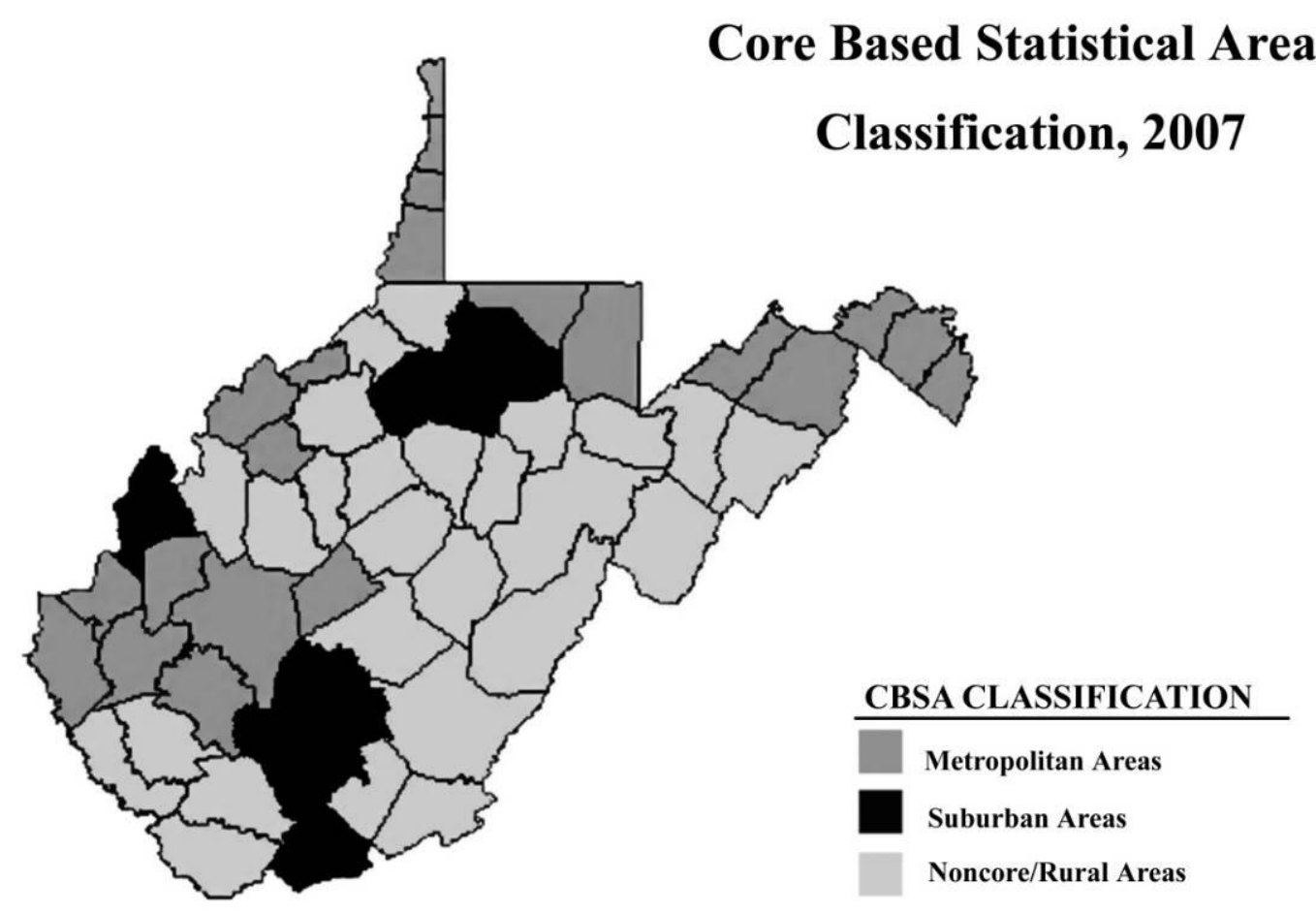

Figure 1.2. Counties in West Virginia were statistically classified into metropolitan, suburban, \& noncore/rural areas in West Virginia. This map depicts the uneven distribution of the population throughout the state therefore creating areas requiring critical resources. Adapted from "Demographics and Economic Profiles: West Virginia" by K. Miller, 2006, source: Office of Management and Budget and U.S. Census Bureau CBSA Classification, 2007. 
West Virginia citizens residing in rural areas are older, have less education, have lower incomes and have poorer health than the metropolitan population. Reasons for poorer health can be attributed to distance from health and social services (Goins and Krout, 2006). In rural areas, number of services available declines significantly (see Figure 1.3).

\begin{tabular}{|cccc|}
\hline $\begin{array}{c}\text { Urban } \\
2,000,000\end{array}$ & $\begin{array}{c}\text { Suburban } \\
200,000\end{array}$ & $\begin{array}{c}\text { Regional Ctr. } \\
20,000\end{array}$ & $\begin{array}{c}\text { Town } \\
2,500\end{array}$ \\
\hline & & & \\
\hline Good & Adequate & Limited & No \\
Service & Service & Service & Service \\
\hline
\end{tabular}

Figure 1.3. Community size can indicate the amount of services available. Towns with populations under 2,500 people had to travel outside their community to receive treatment. Rural areas offer smaller clientele and generally lower incomes which prevent services from having the ability to support the business. Many times businesses leave small towns to find communities that can financially support the business. From "Service Delivery to Rural Older Adults: Research, Policy, and Practice" by T.R. Goins, A.J. Krout, 2006, Transportation and Aging; Challenges in Rural America, p. 185, Copyright 2006 by Springer Publishing Company, Inc.

Current treatment options generally require patients to commute some distance to medical facilities for chemotherapy or radiation. Multiple visits may be necessary daily, weekly and/or monthly depending on the diagnosis (Goins \& Krout, 2006). The diagnosis dictates the type of facility and treatment necessary which is another obstacle for West Virginia since health services are more limited in comparison with more populated and urbanized states. 
West Virginia has been recognized as a Medically Underserved Area or MUA (West Virginia Department of Health \& Human Resources [WVDHHR], 2008; see

Figure 1.4). An area is categorized as underserved when it exemplifies four qualities; low ratio of primary care physicians per 1,000 populations, high infant mortality rate, high percentage of population below the poverty level, and high percentage of the population 65 and older. Medically underserved populations experience a shortage of health professionals and services (“Summary of Proposed Rule on Designation of Medically Underserved Populations and Health Professional Shortage Areas: 73 Fed. Reg. 11232," 2008).

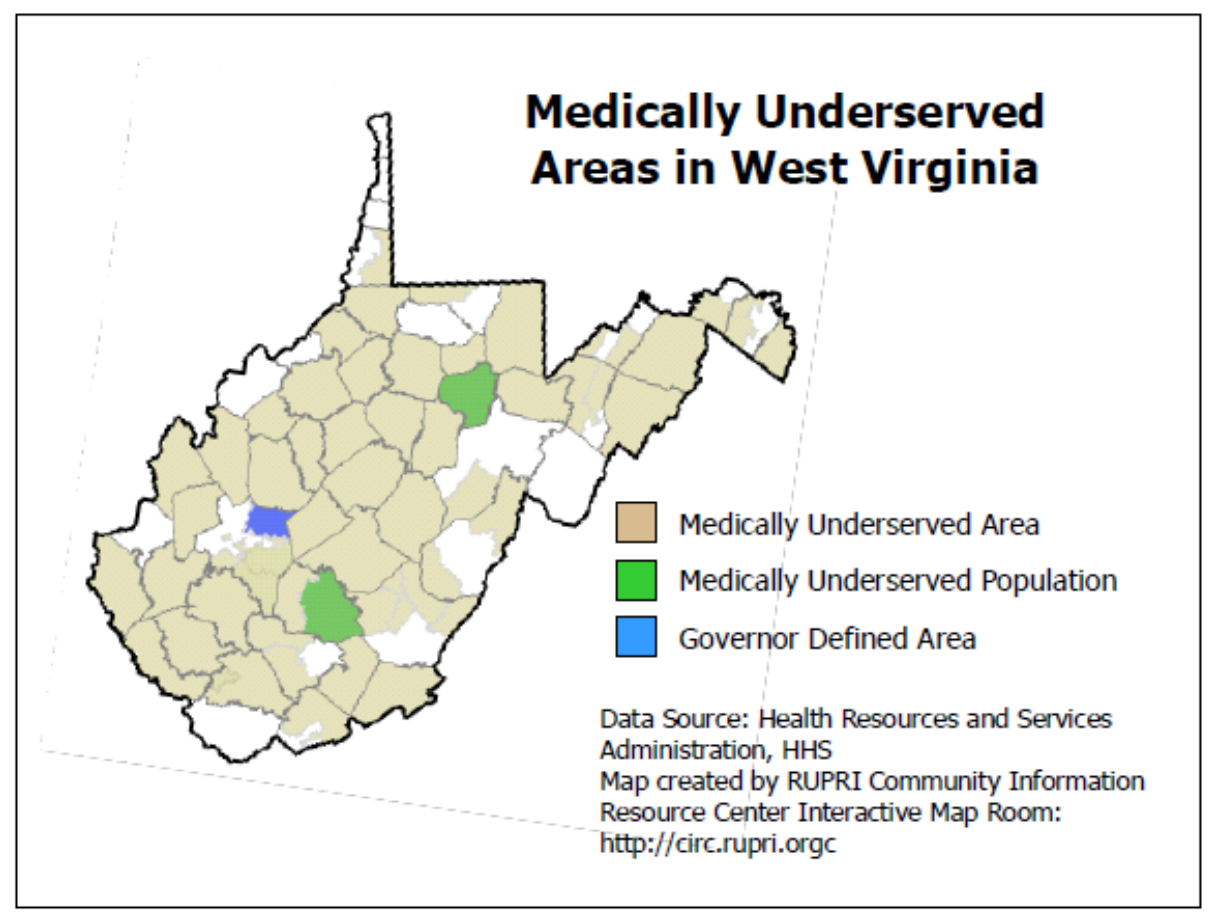

Figure 1.4. Medically underserved areas share a close similarity to the population dispersal in West Virginia. Although there is a difference between medically underserved areas, underserved populations, and governor defined areas. Underserved populations can lie outside a metropolitan area causing this effect. Underserved areas are a product of rural areas. From "West Virginia Medically Underserved Areas (MUAs)" by West Virginia Department of Health and Human Resources, 2008. Copyright 2008 WVDHHR. 
Diversity and limited finances contribute to shortages of health professions and services in rural areas. The inability to produce funds means a healthcare provider would forego financial gain. Often individuals that come from small towns are seeking better education and employment opportunities but are frequently faced with this dilemma of financial sacrifice. Many people cannot afford the pay reduction in their salary or to take a job that may not provide health insurance.

Age. In 2000 West Virginia's citizens were among the oldest in the United States with an elderly population that exceeds $15 \%$ of West Virginia's entire population ("U.S. Census Bureau," 2010; see Figure 1.5). As generations grow older, mental and physical capacities can diminish resulting in the loss of the ability to drive vehicles (Goins \& Krout, 2006). Studies indicate that rural residents tend to be older, poorer, less educated, smoke cigarettes, and have a higher chance of being uninsured ("Intercultural Cancer Council Rural Poor and the Medically Underserved and Cancer,” 2009). Typically these rural communities lack community-based services and service professions common to urban areas (“U.S. Census Bureau,”2010; Miller, K., 2006). Community members have very close ties to one another and they look out for each other. This shared bond of growing together and experiencing life's most important moments can cause individuals to age in place rather than move closer to facilities that could tend to their needs and provide services and care that could potentially save their lives. This problem has been compounded in West Virginia by the exodus of youth in pursuit of better employment opportunities, diminishing ready sources of help and transportation for the elderly (Goins \& Krout, 2006). 


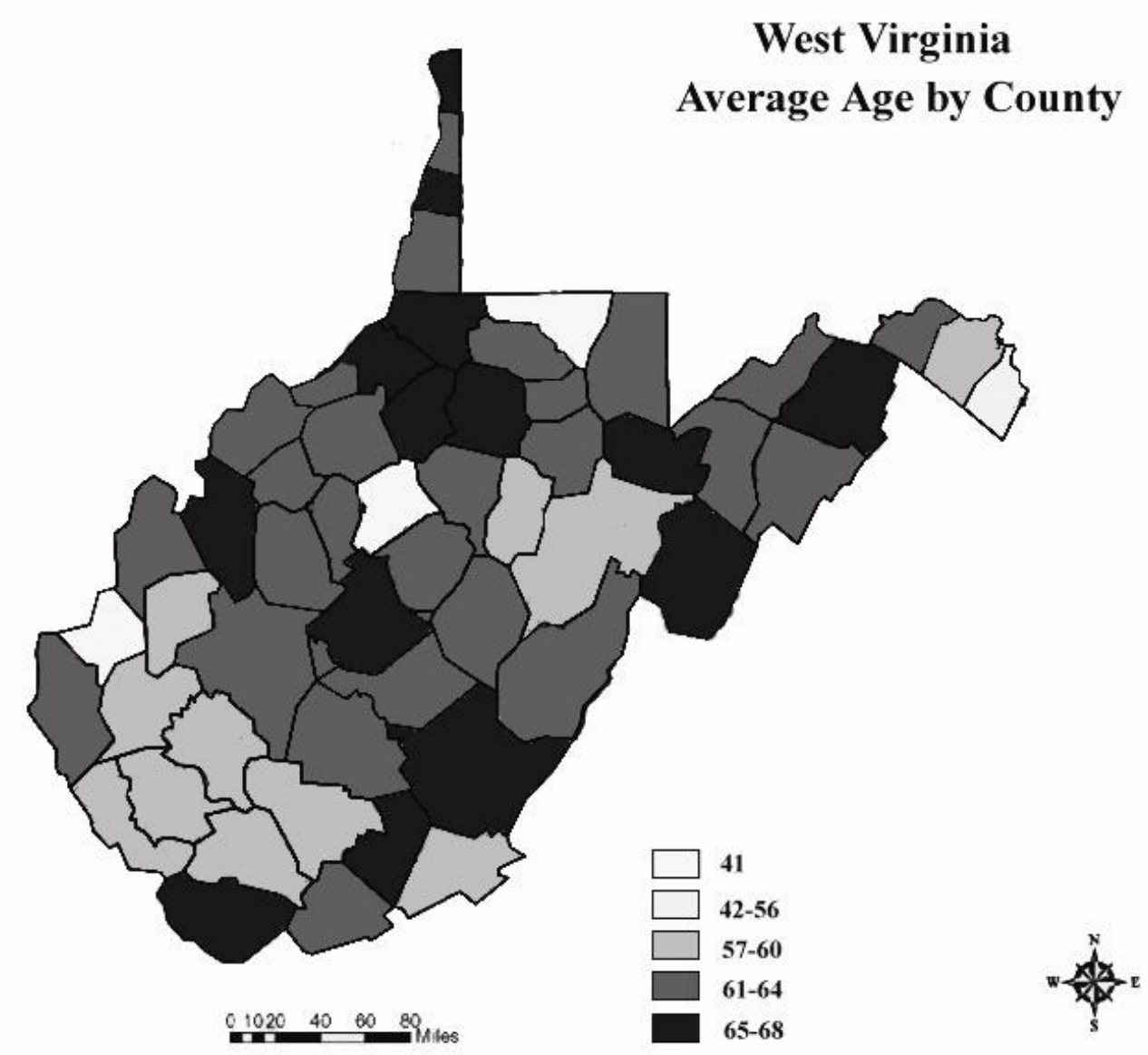

Figure1.5. Average age groups by county for the state of West Virginia share a direct correlation with all of the previously mention information about where metropolitan areas are versus rural areas and if the area is medically underserved. The counties lacking resources have been identified as an older population and the younger counties are located in more developed areas. Adapted from "United States Census 2000" by U.S. Census Bureau, 2000, Census 2000 data for the state of West Virginia. Copyright 2000 by U.S. Census Bureau.

Transportation. Geography and distance can also make access to services difficult for patients. West Virginia's terrain, although beautiful, creates major problems for transportation (Goins \& Krout, 2008). For instance, a West Virginian patient residing Tunnelton, a small town in Preston County, may need to travel twenty-seven miles or about fifty-four minutes to receive care like radiation and/or chemotherapy to a hospital, 
outpatient clinic, or cancer care center in Morgantown West Virginia ("Get Directions," 2011).

Programs like the Transportation for Health Initiative have been created to help provide transportation to those living in rural places, but there are limitations and inconveniences with the timing of patient's appointments and frequency of necessary treatments. The Transportation for Health Initiative is currently operating in five counties of West Virginia: Morgan, Preston, Grant, Pendleton, and Hardy. Preston County has the highest number of rural roads in the state. Transportation is offered for primary care, follow-ups for urgent care, and pharmacy services. A scheduler makes appointments and a dispatcher makes the arrangements but priority is given to individuals who have no other means of transportation, are unable to afford the full cost of transportation and/or exhibit the potential to neglect follow-up care due to a lack of transportation regardless of age (Hott, 2010).

Terrain. West Virginia actually occupies 24,231 square miles and is mainly rural due to the location and higher elevations in the Appalachian Mountains (see Figure 1.6). The terrain in West Virginia is unique, for it is mostly rural and it is geographically centered in the Appalachian Highlands in the southeast of the United States. The average elevation is 1,500 feet above sea level. The state is divided by the Ridge and Valley region and the Allegheny Plateau. The Ridge and Valley covers about one-fifth of the state's eastern border and provides scenic views of mountains and lush river valleys. 


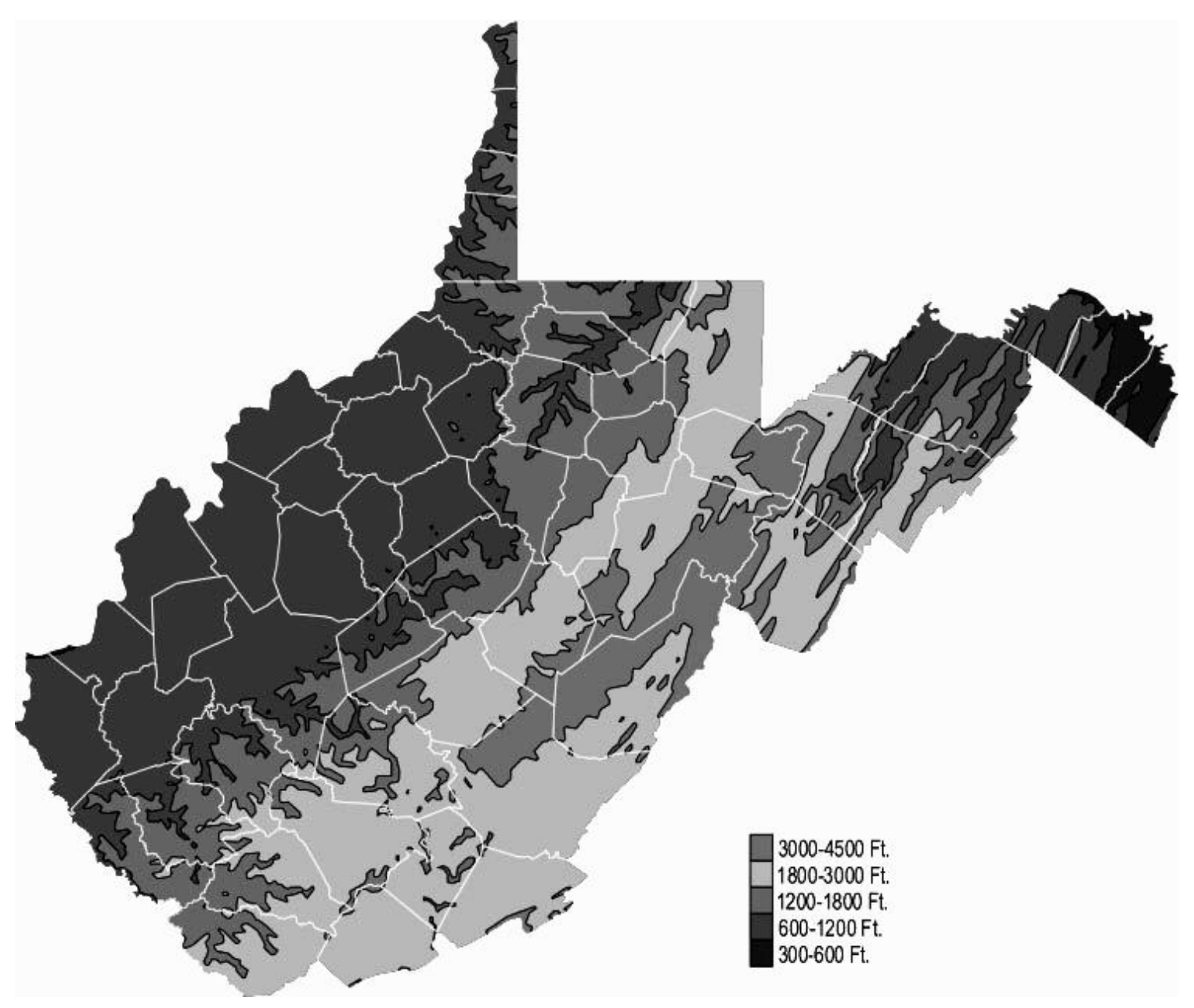

Figure 1.6. An elevation map of West Virginia clearly indicates that the state is primarily mountainous and rural. The state is located in the middle of the Appalachian Highlands and Alleghany Plateau. The average elevation is 1,500 ft. above sea level. The counties that are in lower elevations have more metropolitan areas than those in the higher elevations. Adapted from "West Virginia State Map Collection" by B. Cole, 2008, Geology.com, Copyright 2008 by Map Resources.

The rest of the state is comprised of the Allegheny Plateau which includes the Allegheny Mountains on the eastern side of the plateau. The Allegheny Plateau has very high elevations because the bedrock is chiseled away by the river valleys that run through the area. The highest point is Spruce Knob which is 4,861 feet above sea level. The 
western side of the plateau gently slopes down to the Ohio River Valley ("How Stuff Works,"2011).

These geographical features have limited the construction of many interstates, highways, business routes, streets, and back roads (see Figure 1.7). Roads such as interstate 79 (I-79) or interstate 64 (I-64) are used as primary routes taken by larger vehicles, but tertiary state roads like US-40, US-50, US-19, US-219, US-119, etc.; are other roadways that commercial vehicles have permission to utilize as long as they meet specific size and weight criteria for the state of West Virginia ("State of West Virginia," 2011). 


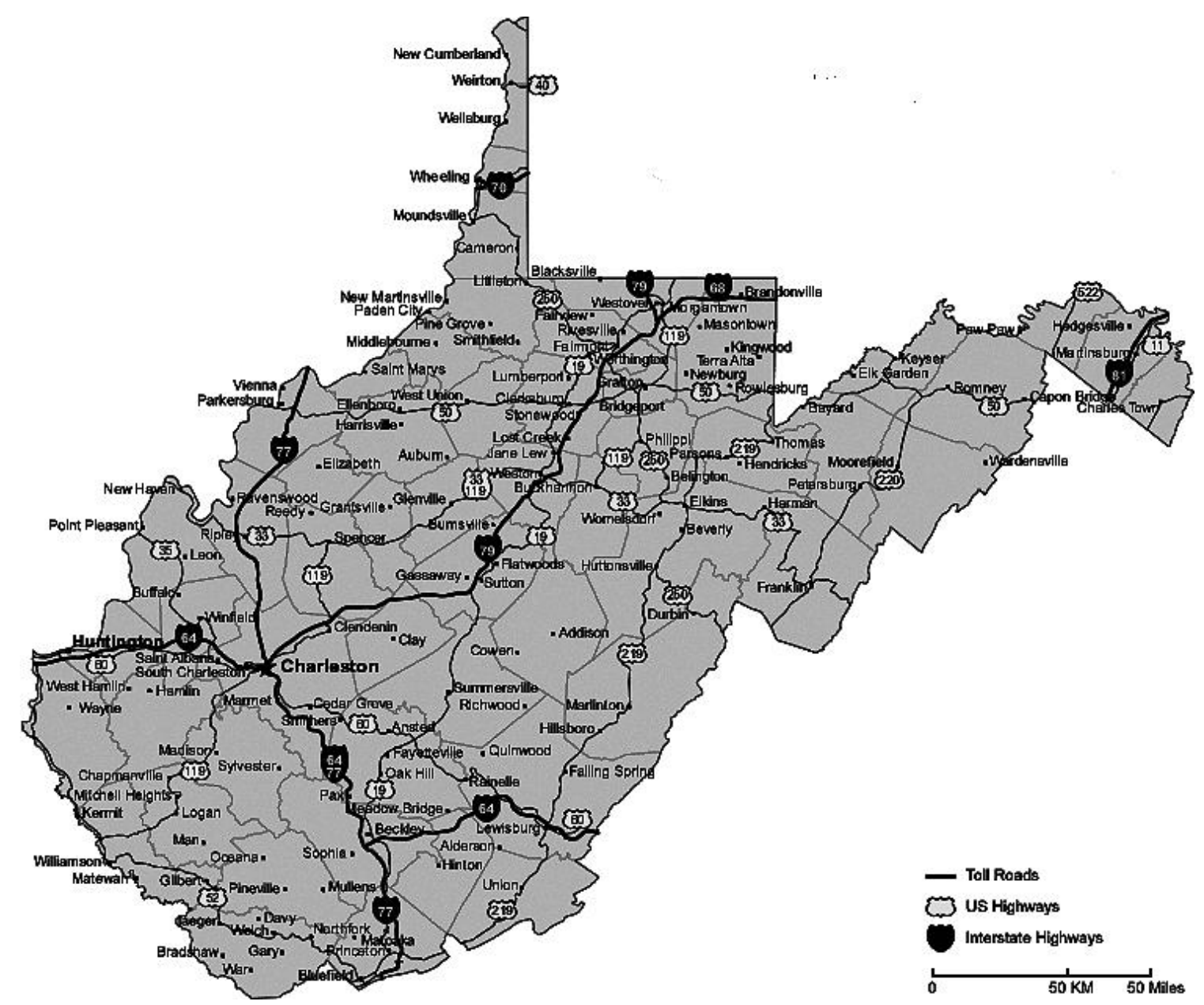

Figure 1.7. This road map of West Virginia outlines the primary and tertiary access routes throughout the state. The southern part of the state has more primary access points whereas the northern part of the state has more tertiary roads to access the larger routes. Adapted from "West Virginia State Map Collection” by B. Cole, 2008, Geology.com, Copyright 2008 by Map Resources.

In rural areas, roads smaller than tertiary roadways act as access points to these larger roads which make them crucial when trying provide healthcare to rural communities. Seasonal weather changes can weaken road integrity which subsequently can cause sudden road closures, and limits access points to larger or main roadways. Since rural communities lack many places to receive care, they are generally the areas that experience the larger problem of poor transportation. 


\section{Education}

Forty-three percent of the adult population in West Virginia has less than a high school education while thirty-two percent of the population lives in poverty (Miller, K., 2006). Rural communities often have limited internet access to clarify information or provide a way for individuals to connect and network with others that might be going through similar events (Goins \& Krout, 2006; Hewitt, Ganz, and Hewitt, 2007). Patients without access may feel isolated in their medical journey if they cannot find a way to connect or reach out to others (Hewitt, Ganz, \& Hewitt, 2007). The barriers faced by West Virginians seeking proper healthcare are summarized in Table 1 below.

Table 1.1.

Summary of Cultural Barriers Experienced by Users in West Virginia

\begin{tabular}{|l|l|}
\hline Cultural Unit Issues & Application in this project \\
\hline Accessibility & $\begin{array}{l}\text { Located in the Appalachian Mountains, pockets of small } \\
\text { communities have caused issues for accessibility to } \\
\text { health services. }\end{array}$ \\
\hline Rural Healthcare Services & $\begin{array}{l}\text { Southern WV is experiencing a high rate of Medically } \\
\text { Underserved areas. }\end{array}$ \\
\hline Education & $\begin{array}{l}\text { At least 15\% of WV's population is considered elderly } \\
\text { and many do not have transportation or finances to } \\
\text { receive care. Besides medical charges, unanticipated } \\
\text { costs for travel, sleeping accommodations depending on } \\
\text { distant from facility, food, etc., pose problems for the } \\
\text { elderly. }\end{array}$ \\
\hline $\begin{array}{l}\text { 43\% of WV's adult population is WV has less than a } \\
\text { high school education and 32\% of the population lives in } \\
\text { poverty. Older generations worked in the coal industry } \\
\text { and currently face the repercussions. Providing } \\
\text { education about the illness could possibly prevent future } \\
\text { cases or lower the number of cases filed per year. }\end{array}$ \\
\hline
\end{tabular}




\section{CHAPTER TWO: LITERATURE REVIEW}

\section{Cancer}

West Virginia's mortality rate from cancer is the fifth highest in the U.S.

Research suggests a causal relationship between cancer and certain behaviors (smoking, chewing, mining.....etc.). West Virginia has an exceedingly high rate of tobacco use in junior and senior high schools. In the state of West Virginia, it is estimated that $33.7 \%$ of youth in grades 9-12 smoke or use some type of smokeless tobacco ("Tobacco," 2009). Mining and coal dust pollution are responsible for health issues not related to tobacco use such as black lung disease.

Black Lung Disease, also known as coal workers' pneumoconiosis (CWP), is caused by long exposure to coal dust. It is a common affliction of coal miners, others who work with coal, and those who inhale silica dust. It closely resembles the long-term effects of tobacco smoking. Inhaled coal dust progressively builds up in the lungs and is unable to be removed by the body; that leads to inflammation, fibrosis, and in the worst case, necrosis. Necrosis is the death of one or more cells, or of a portion of tissue or organ, resulting from irreversible damage (Healthwise, 2008). In 1969 the Federal Mine Safety and Health Act was passed and it cut back the number of cases found by $90 \%$. Recently, however, the number of reported Black Lung cases has been on the rise. Incidents among miners who have worked 24 years or less, jumped from $2.6 \%$ to $6 \%$ and miners working 25 years or more went from 4\% in 1997 to 9\% in 2006 (Bass, 2009) 
More than one third of cancer deaths in West Virginia resulted from Lung Cancer (“Tobacco," 2009). Surveys show that besides lung cancer, skin and lip cancers were also responsible for cancer-related death. Cancers can be also attributed to obesity and dietary patterns. For example, diets high in fat and low in fiber have been connected to colon and rectum, uterus, prostate and breast cancers. Obesity may raise cancer risk because fat cells produce a form of estrogen called estradiol that promotes rapid division of cells, increasing chances of a random genetic error while cells are replicating, which can lead to cancer (National Cancer Institute, 2004). Currently West Virginia is ranked fourth (following Tennessee) in the nation for obesity (Adult Obesity Rankings by State, 2010). Education to alter risky behaviors has proven an effective tool in cancer prevention. Coupled with early detection and treatment this could bring significant health benefits to areas, such as rural communities, that have not previously had access to these resources (“Tobacco," 2009).

\section{Cancer Treatment}

Once a slow, silent killer with no consistent proven type of treatment, cancer now has a more promising diagnosis with advancements in medical technology. Many new and old types of treatments are readily available for different prognoses. Most institutions that provide oncology services will offer one or more conventional diagnostic and/or therapeutic services therapies. Diagnostic services are anything that is used to diagnose a problem. Examples would be things like mammograms, ultra-sounds, positron emission tomography (PET/CT) scanning, surgery, etc. Therapeutic services are treatments used to treat and heal patients. This would include chemotherapy, radiation therapy, and hormone therapy (Cancer Treatment Centers of America [CTCA], 2008). Facilities such as 
Edwards Comprehensive Cancer Center offer most of the treatments previously mention but they also have an image guide radiology therapy, phlebotomy, a linear accelerator, and conduct clinical trials (Edwards Comprehensive Cancer Center [ECCC], 2009). Fairmont General Hospital offers all of the conventional treatments along with nuclear medicine and access to a Magnetic Resonance Imaging (MRI) machine five days per week ("Fairmont General Hospital," 2009). These scientific treatments are the most commonly used, but advances in technology will soon replace traditional methods and hopefully produce a cure for cancer.

Chemotherapy. Chemotherapy is the most common treatment approach to combat cancer (CTCA, 2011). Drugs can be administrated intravenously, orally, topically, or by injection. Injecting the medication intravenously allows the medicine to spread through the blood system more rapidly. It attacks and kills cells that quickly divide, like cancer cells and healthy cells such as bone marrow (Mayo Clinic, 2008). The chemicals that are in the medicine attempt to destroy cancer, but in the process patients may experience a variety of side effects. Hair loss, vomiting, fatigue, bleeding, loss of appetite, susceptibility to infection, all have been known reported symptoms. Chemo cannot tell the difference between healthy for growing cells and cancerous cells which explains why the entire body is affected so greatly. Only when a patient goes off of chemotherapy will their bodily functions return to normal condition (CTCA, 2011).

Radiation. Radiation, another type of treatment, has been used to kill cancer cells in combination with chemotherapy and by itself. There are two types, external radiation therapy or internal radiation therapy (brachytherapy). External radiation therapy is received much like X-rays. Intense beams of radiation are delivered to a specific section 
of the body with high accuracy through the use of machines like linear accelerators or orthovoltage x-ray machines. The most commonly used types of radiation are x-rays and gamma rays (Ehealth MD, 2008). Acting as an alternative, internal radiation uses substances rather than rays to administer medication.

Internal radiation involves placing radioactive substances within the body near or in the cancerous site. Such solutions include cesium, iridium, and iodine. The implants may or may not be permanent and patients usually remain in the hospital for at least one day (Ehealth MD, 2008). By using this method, higher doses of radiation are delivered to a smaller area than external therapy. Receiving internal radiation at the same time as external treatment is common as well.

Radio Waves. Radio waves are one of many new technologies under investigation. The Kanzius Cancer Treatment was developed by John Kanzius who was given diagnosis of Leukemia in 2002 (Kanzius, 2007). The machine works by shooting radio waves at a cancerous site that has been injected with a metallic solution to heat the molecules to the point where they actually cook. Only the injected site is affected and the surrounding healthy tissue is left undamaged (Kanzius, 2008). The machine is being evaluated and tested by scientists and advocates are forecasting human trials will soon follow. Other treatments such as gene therapy, nanotechnology with diamonds and optical devices are in laboratory trials. They have promising futures but most new cancer treatments are years from human/clinical trials.

Alternative/Complementary Options. In juxtaposition to scientific methods of treatment, alternative or complementary options are available. Some examples of 
complementary treatment are; acupuncture, chiropractic care, aromatherapy, art therapy, music therapy, spiritual therapy, group therapy, support groups and/or counseling (National Cancer Institute, 2009). Aromatherapy, art therapy, music therapy, spiritual therapy, group therapy, and/or counseling are types of mind-body medicines that are used to support cancer patients during treatment, those in remission, and survivors of cancer. Chiropractic care and acupuncture are alternative options that support the physical body.

The use of complementary and alternative medicines (CAM) along with conventional treatment has recently been increasing due to awareness and the positive outcomes documented thus far. The Center for Complementary and Alternative Medicine has deemed integrative medicine or an "integrative practice model" as a treatment plan that consists of traditional methods and CAM to provide patients with optimum results. Facilities, practitioners, and administrations have started to actively introduce cancer patients to CAM, natural products, and other services offered. Information about alternative treatment methods and its reintegration to modern medicine has reached the public through marketing, internet, and exposure through general conversation, although the quality of the information is impossible to control. The responsibility of maintaining reputable material or ensuring validity of facts falls back on agencies, facilities, practitioners, and administrations. This is difficult to do in metropolitan areas and even more formidable in rural areas such as West Virginia. Receiving treatment for cancer and living with it can cause significant physical stress and pain to patients and these physical supports, like acupuncture and chiropractic care, are helping patients to obtain some relief. (CTCA, 2011). 
Support groups form in hospitals, communities and online as well. They provide comfort to others that have common issues. These systems can also provide information by individuals sharing their experiences. Groups also exist for members of the patient's family. Together they can provide the support that is needed to survive all aspects of cancer but victims can lose their battle whether or not they are involved in a group. Support groups merely exist to boost morale. Members of the group are not limited to those undergoing immediate treatment. They also include former patients that have become survivors. Participation by survivors provides hope to those undergoing treatment.

Natural treatments are not typical suggestions of treatment by doctors, for most medical schools do not teach these methods. To receive natural treatment many patients seek specialists or resort to research through books and the internet. Natural treatments can be organic substances such as mushrooms, diets, or even supplements (Cancer Research UK, 2009). Besides physical treatments, environments are now being designed to help promote healing.

\section{Treatment Locations}

Historically, treatment for cancer was provided in hospitals, but as medicine evolved specific specialties developed. Patients gained the luxury of having options as to where they could receive treatment and talk with doctors. Between 2000 and 2005 the hospital industry spent $\$ 100$ billion on new buildings and renovations. In 2005 , the Robert Wood Johnson Foundation forecasted that an additional \$200 billion will be spent over the next 10 years. New medical technology such as computers for patient record 
retrieval and new ideas in total care that include and extend beyond the patient, have triggered the boom in medical construction and renovation. Special units within the hospitals like infusion centers opened. Hospitals dedicated to cancer, outpatient facilities, oncology offices, and general cancer centers were established. The ability to receive care was expanding to reach a larger population and help alleviate overcrowding due to the growing number of cases of cancer found each year. Examples of these places are; Fairmont General Hospital in Fairmont, David Lee Outpatient Cancer Center in Charleston, WVUH-East Cancer Program in Martinsburg, Mary Babb Randolph Cancer Center West Virginia University in Morgantown, Betty Puskar Breast Cancer Center in Morgantown, St. Mary’s Medical Center in Huntington, St. Joseph’s Hospital in Parkersburg, Cabell Huntington Hospital and Edwards Comprehensive Cancer Center in Huntington, West Virginia (Stoneking, 2008). Free-standing outpatient facilities make receiving treatment for patients more convenient because they allow more access to those residing in less urban areas, provide more parking, and allow patients to been seen and treated faster due to smaller patient volume than a conventional hospital (Cedar-Sinai, 2011).

Although it is not the only treatment facility in the state, West Virginia University Hospital (WVUH) contains both inpatient and outpatient facilities. The hospital is under the direction of the West Virginia United Health System which was created in 1996 and is the largest care provider in the state of West Virginia. West Virginia University Hospital covers 500,000 square feet, has 7,839 employees, and over 500 beds. It is the second largest employer in the state (WVU Healthcare, 2006). Recently the Mary Babb Randolph Cancer Center, the hospital's cancer center, opened a \$22 million expansion 
which has double the space and allows for a larger research facility for cancer. This research center is dedicated to finding a cure for cancer or alternate solutions which diminish cancer-related deaths in West Virginia.

In 2007, Christine Mills, founder of the charities 'Hope for Tomorrow \& Art to Give' helped create the world's prototype Mobile Oncology Unit which was constructed in Britain (see Figure 2.1). The hope is to transport life-saving care to patients rather than having patients travel to a facility every day or week (Hope for Tomorrow, 2010).

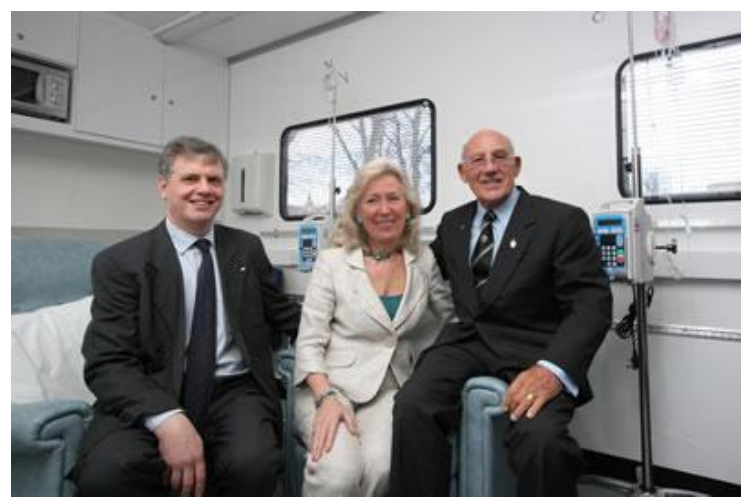

Above: Medical Director Dr. Sean Elyan (left), Founder Christine Mills (center), Sir Stirling Moss OBE (right)
Below: Gloucestershire's first Mobile Chemotherapy Unit. It is able to accommodate 5 patients at a time and see 20 patients per day

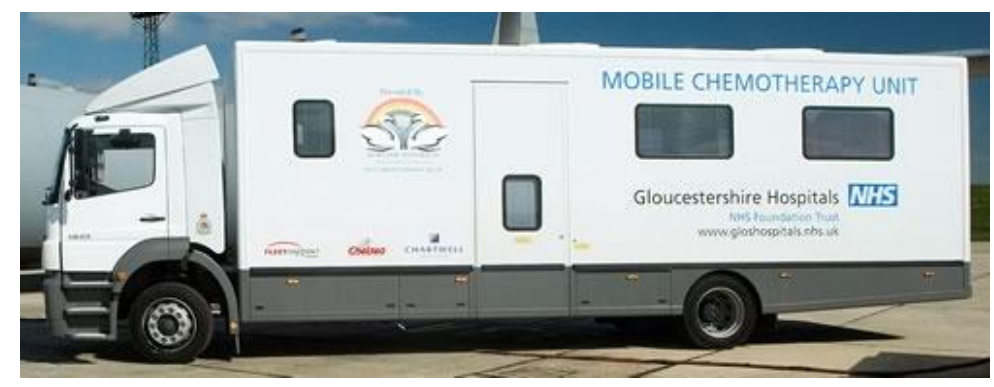

Figure 2.1. Hope for Tomorrow's Mobile Chemotherapy Unit can serve as a perfect presently functioning prototype for the purpose of this purpose. From "Mobile Chemotherapy Unit Project" by Hope for Tomorrow, 2010. Copyright 2010 by Hope for Tomorrow and Art to Give. 
Care in this context encompasses treatment and/or prevention and early detection. This mobile unit was first used in Glouchestire, England. Units are now in use to serve remote areas in the state of Texas and Rio Grande Regions under the sponsorship of the University of Texas. Since 2001 mobile units have provided treatment and care to rural Texas cancer patients by centralizing the units in places that larger rural populations can access (Business Wire, 2001). Most of the terrain in Texas is relatively flat and the weather is hot and dry. Barriers for Texas are the heat and distances. Refrigeration and a vehicle's ability to remain reliable on long distances are the largest challenges to overcome.

Mobilization of cancer care in the United States has typically been limited to early diagnosis. Many hospitals have purchased mobile Positron Emissions Tomography (PET) imaging units. These machines capture the body's physiologic changes, revealing tumors, and tissue activity that are often missed by Computed Tomography (CT) and Magnetic Resonance Imaging (MRI) units. Mobilizing PET units, doctors are given the advantage of catching cancer diagnosis's in earlier stages (Business Wire, 2001). Shakopee Mdewakanton Sioux Community in Prior Lake, Minnesota has a mobile medical unit that functions primarily as a mammography and cancer screening unit but is also prepared to serve as an emergency response vehicle for the entire area and local Native American Reservations (see Figure 2.2). It has two radiology suites, a laboratory, large open multifunctional spaces, and has radio, telephone, satellite, internet, and technical capabilities for tactical planning for coordinating services in case of a disaster or emergency (Shakopee Mdewakanton Sioux Community, 2009). 


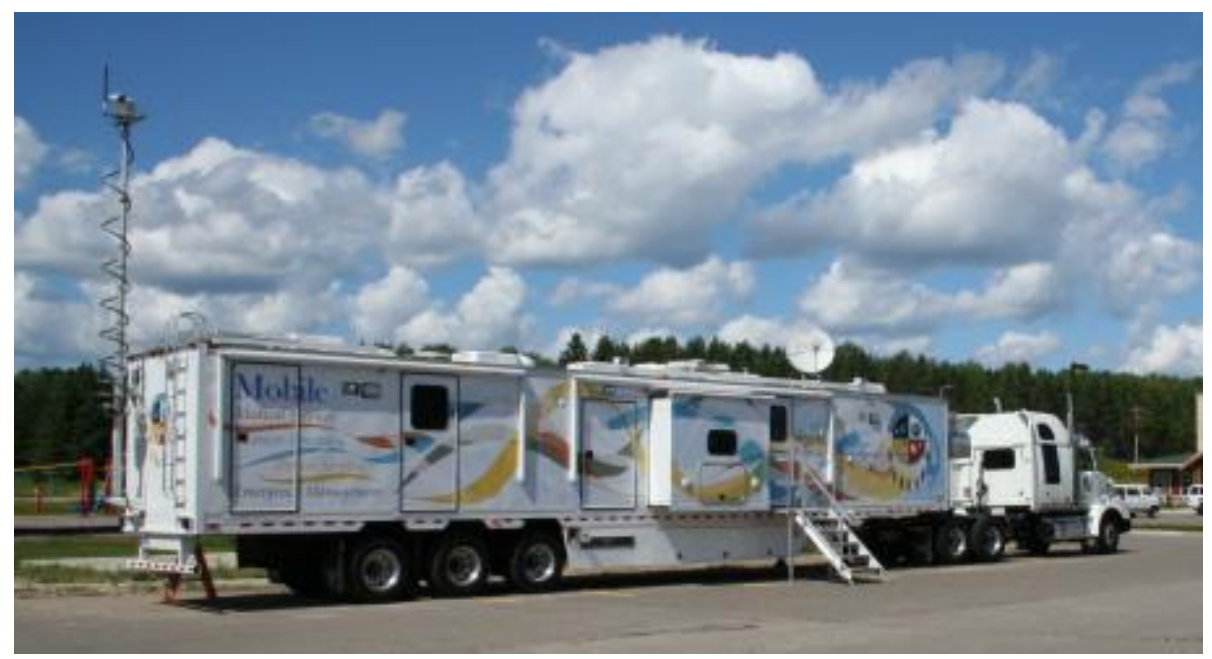

Figure 2.2. The Shakopee Mdewakanton Sioux Community Multi-Functional Mobile Medical Unit is a joint project between the Shakopee Mdewakanton Sioux Community Health Department and Mdewakanton Emergency Services. From "The Multi-Functional mobile Medical Unit Fact Sheet” by Shakopee Mdewakanton Sioux Community, 2009.

A mobile oncology unit could take the concepts behind both the Shakopee Mdewakanton Sioux Community Multi-Functional Mobile Medical Unit and mobile PET imaging units and extend beyond diagnosis to actually provide the necessary treatment, care, education, and follow-ups. Constructing a unit that can make treatment more readily available would not only benefit a patient but also the health care system.

West Virginia University Medical Center has adopted its first mobile program, but it focuses on diagnosis and prevention specifically targeted towards breast cancer. Recently, the Mary Babb Randolph Cancer Center in Morgantown West Virginia purchased, what has come to be known as, "The Bonnie Bus" inspired by the Bonnie Wells Wilson Mobile Mammography Program (see Figure 2.3). West Virginia University owns and operates the bus which was made possible by a $\$ 2.5$ million donation from Jo and Ben Statler to the Mary Babb Randolph Cancer Center. 


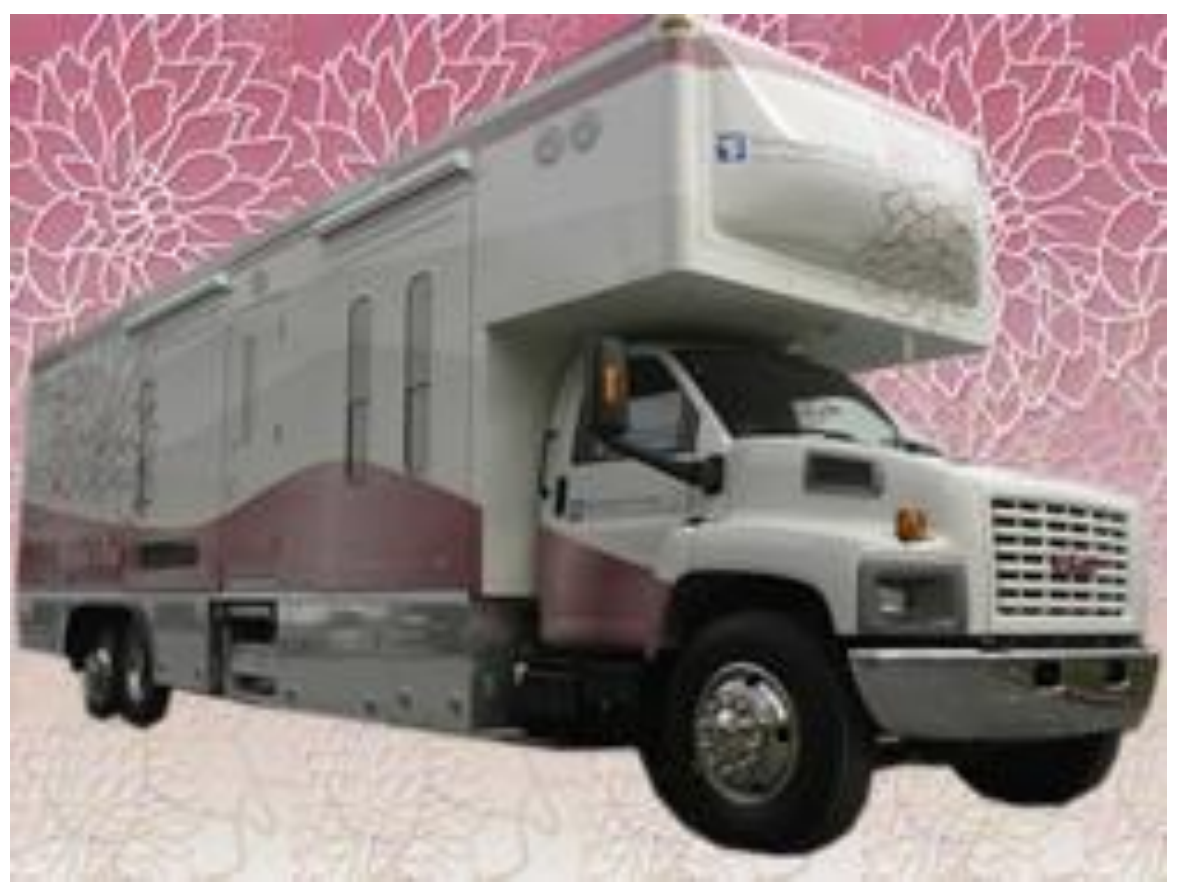

Figure 2.3. WVU Hospital's Mobile Mammography Unit "The Bonnie Bus". A forty foot long bus that is equipped with a patient education area, small kitchenette, restroom, and waiting area. From “Bonnie's Bus-Mobile Mammography Program” by Mary Babb Randolph Cancer Center, 2011, Mary Babb Randolph Cancer Center at West Virginia University.

The purpose of the bus was to create a mobile mammography unit that would serve as a research database, establish networks between doctors and hospitals, and deliver care to women across the state. The mammograms offered are not free, but billing to third parties is provided and for women who lack insurance, funds will be provided by government or nonprofit charities (Mary Babb Randolph Cancer Center, 2011).

The Bonnie Bus will focus on West Virginia counties such as McDowell that have high breast cancer mortality rates and are considered medically underserved. Transportation, unemployment, insurance, and access have been and currently are major barriers for patients. The medical field is working hard to find new treatments and a cure 
for cancer while the design industry and this thesis has taken a different approach by

focusing on the places patients receive care and creating environments that would

promote healing. This project hopes to bridge that gap between design, medical

treatment, and financial profitability through mobile units (Mary Babb Randolph Cancer

Center, 2011). 


\section{CHAPTER THREE: METHODOLOGY}

This project involves identification of design guidelines for a mobile oncology unit for use in rural West Virginia. The primary methodology employed will be design process. Secondary data from evidence-based design will also serve as a resource.

\section{Design as a Research Guideline}

Human knowledge can be divided into three cultures: science, humanities, and design. Each has approach employs a particular focus, question, method, and value (see Table 3.1). Design is unique both as a research orientation and as a research process. "Stripped to its essences, [design] can be defined as the human capacity to make our

environment in ways without precedent in nature, to serve our needs, and give meaning in our lives (Heskett, 1997).” 
Table 3.1.

The three cultures of human knowledge offer diverse and complementary ways of knowing.

\begin{tabular}{|l|l|l|l|}
\hline & Science & Humanities & Design \\
\hline Focus & Natural world & Human experience & Man-made world \\
\hline Question & What is? & $\begin{array}{l}\text { What does it mean to } \\
\text { me? }\end{array}$ & $\begin{array}{l}\text { How can I make } \\
\text { it better? }\end{array}$ \\
\hline Methods & $\begin{array}{l}\text { Experiment } \\
\text { Pattern recognition } \\
\text { Analysis } \\
\text { Classification } \\
\text { Deduction }\end{array}$ & $\begin{array}{l}\text { Analogy } \\
\text { Metaphor } \\
\text { Criticism } \\
\text { Valuation } \\
\text { Induction }\end{array}$ & $\begin{array}{l}\text { Modeling } \\
\text { Pattern formation } \\
\text { Synthesis } \\
\text { Conjecture } \\
\text { Abduction }\end{array}$ \\
\hline Values & $\begin{array}{l}\text { Objectivity } \\
\text { Rationality } \\
\text { Neutrality } \\
\text { "Truth" }\end{array}$ & $\begin{array}{l}\text { Subjectivity } \\
\text { Imagination } \\
\text { Commitment } \\
\text { "Justice" }\end{array}$ & $\begin{array}{l}\text { Practicality } \\
\text { Creativity } \\
\text { Empathy } \\
\text { "Fit" }\end{array}$ \\
\hline
\end{tabular}

Note. This table prepares a designer with questions to ask stakeholders in the 3rd step "Collect" of the design process which will be explained and discussed later in this chapter. Adapted from "Designerly Ways of Knowing” by N. Cross, 1982, Vol. 3, p. 221227. Copyright Springer-Verlag London Limited 2006.

The most common type of research is scientific and focused on the natural world. It asks the basic question of "What is?" The scientific approach utilizes experiments, pattern recognition, analysis, classification, and deduction as a means to reach solutions. This type of analysis is recognized for employing values that are rational, neutral, and objective. Science sticks to the facts and presumes to present universal truth. In contrast to science, the humanities concentrate on human experience, asking "What does it mean to me?" or "How do I portray the human experience?" Preferred methods include analogy, metaphor, criticism, valuation, and induction. In stark contrast to the scientific approach, the humanities apply subjectivity, imagination, commitment, and "justice" 
rather than objectivity and rationality. The third culture identified is design (Cross, 1982; Banathy, 2000).

Design focuses upon the man-made world and poses the question, "How can I make it better?" or "What should be?" It employs modeling, pattern formation, synthesis, conjecture, and abduction as methods to answer those questions. Design research is value added. Design promotes practicality, creativity, empathy, and concern for the best "fit" for each situation (Cross, 1982; Banathy, 2000). This thesis applies data collected from scientific and humanities research and uses the design process as a resource to create a set of guidelines that could help create an optimal design solution.

\section{Design Process as a Methodology}

The design process is a systematic problem solving strategy, with criteria and constraints, used to develop possible answers to problems, satisfy human needs and wants, or narrow down possible solutions to one final choice. Although the design process ultimately narrows down decisions, this process is an iterative system, meaning that it is repeated numerous times and decisions are revisited constantly (Kilmer and Kilmer, 1992). There are many closely related versions of the design process. The one chosen for this project involves eight steps: commit, state, collect, analyze, ideate, choose, implement, and evaluate (see Table 3.2). 
Table 3.2.

The Design Process

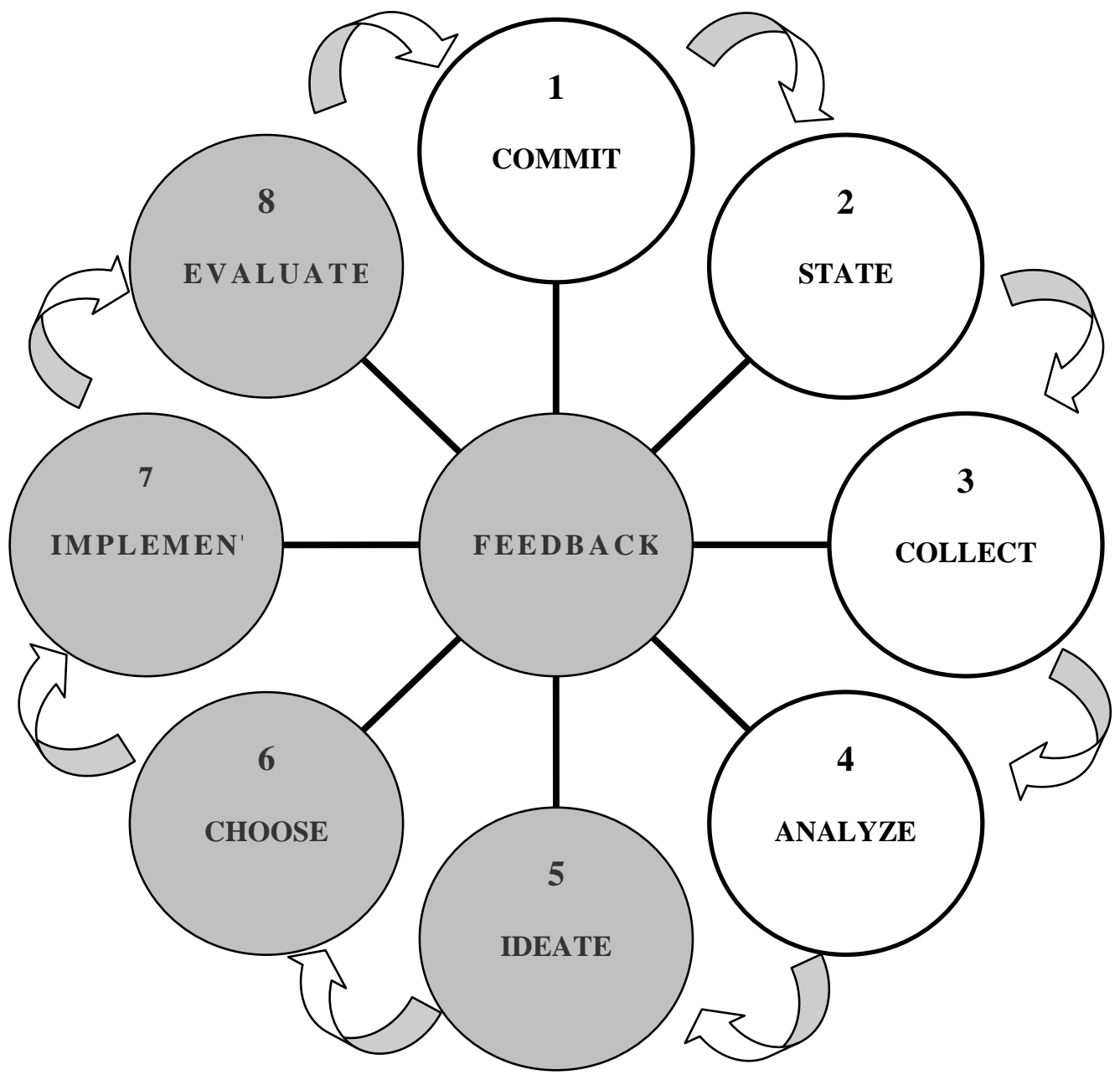

Note. This table depicts the design process and highlights the areas of the process this paper will cover which is phase 1. Adapted from "Designing Interiors," by R. Kilmer \& W.O. Kilmer, 1992, p. 156. Copyright 1992 by Holt, Rinehart and Winston.

These eight steps can be further delineated into two phases, "analysis" and "synthesis." This project is delimited to the analysis phase of the process (see Table 3.3). 
Table 3.3.

Identifying characteristics of "Phase 1: Analysis" of the Design Process

\begin{tabular}{|c|c|c|c|c|}
\hline Phase 1: Analysis & Commit & State & Collect Data & Analyze \\
\hline Purpose & $\begin{array}{l}\text { Accept the } \\
\text { problem } \\
\text { Involvement } \\
\text { Start } \\
\text { Get into the } \\
\text { Situation }\end{array}$ & $\begin{array}{l}\text { Set Goals } \\
\text { Establish } \\
\text { Objectives } \\
\text { Define the } \\
\text { Issues }\end{array}$ & $\begin{array}{l}\text { Gather Facts } \\
\text { Research }\end{array}$ & $\begin{array}{l}\text { Clarify Goals } \\
\text { Break It Down } \\
\text { Scrutinize }\end{array}$ \\
\hline $\begin{array}{l}\text { Designer's } \\
\text { Terminology }\end{array}$ & $\begin{array}{l}\text { Retainment of } \\
\text { Services }\end{array}$ & Feasibility & Programming & Analyze \\
\hline $\begin{array}{l}\text { Project } \\
\text { Development }\end{array}$ & $\begin{array}{l}\text { Client Contact } \\
\text { Proposal/Contract } \\
\text { Secure Contract }\end{array}$ & $\begin{array}{l}\text { Feasibility } \\
\text { Study }\end{array}$ & $\begin{array}{l}\text { Programming } \\
\text { Scheduling } \\
\text { Budgeting } \\
\text { Client Approval }\end{array}$ & Analyze \\
\hline $\begin{array}{l}\text { Methods of } \\
\text { Communication }\end{array}$ & $\begin{array}{l}\text { Telephone } \\
\text { Contact } \\
\text { Referrals } \\
\text { Interview } \\
\text { Letters of Inquiry } \\
\text { Prior Experience } \\
\text { Proposals } \\
\text { Contracts }\end{array}$ & $\begin{array}{l}\text { Graphic } \\
\text { Written } \\
\text { Verbal }\end{array}$ & $\begin{array}{l}\text { Bar Graphs } \\
\text { Matrix } \\
\text { Flow Charts } \\
\text { Diagrams } \\
\text { Interviews } \\
\text { Statistics } \\
\text { Surveys } \\
\text { Written Info } \\
\text { Pattern } \\
\text { Searching } \\
\text { Photographic }\end{array}$ & $\begin{array}{l}\text { Diagrams } \\
\text { Matrix } \\
\text { Charts }\end{array}$ \\
\hline
\end{tabular}

Note. This table depicts phase 1 of the design process which is "commit", "state", "collect data", and "analyze" and specifies more concisely what a designer would actually do in those steps. Adapted from "Designing Interiors," by R. Kilmer \& W.O. Kilmer, 1992, p. 156. Copyright 1992 by Holt, Rinehart and Winston.

The first two steps of the design process (commit and state) have been addressed in Chapters One and Two. The remaining two steps (collect data and analyze) are the subject of Chapter Four. Further clarification of process applications in this thesis is provided below. 
Commit. The first step in any design project is recognizing that there is a problem to be solved and fully embracing the responsibility to solve it. This will generally require dedicated time and attention for a sustained period of time. Deadlines are frequently a factor as well. Merriam Webster defines "commit" as establishing a deliberate course of action such as (a) "a contract committing the company to complete the project on time" or (b) "to pledge or assign to some particular course or use" (Merriam-Webster, 2011b). Between designers and clients, this step may begin with preliminary discussions about a client's needs, expectations, and budget and end with legal documents that form a contractual binding agreement. In a research thesis, this commitment is established by delimitations and limitations. The commitment to providing a welcoming and healing environment that initiates this design process is delimited to

- mobile oncology treatment treatments and supportive therapies

- to underserved (predominantly rural) areas of units (MOTU) engaged in - periodic delivery of selected West Virginia

The limitations imposed by this commitment include criteria that may be better suited to rural than to urban environments. Some specific findings may better fit the challenges of mountain terrains and cultures in West Virginia than those found in other areas and populations.

State. The second step in the design process involves setting goals and objectives and defining issues more specifically. These are the explorations that determine the feasibility of the project and an understanding of what might constitute a realistic outcome. At the "state" step, this thesis was further delimited to 
- the analysis phase of the design process (steps 1-4)

- representing the interests of targeted stakeholder groups (patients, direct care professionals, health administrators, design professionals, researchers);

- in accordance with findings from evidence-based design;

- and subject to relevant facilities parameters (size of mobile units; restriction to ambulatory care; codes and other legal and cultural constraints).

Collect. This step involves research to gather data that will be organized and provided as a published "program." Designers use the term "programming" to describe both product and process. In accordance with the delimitations established in the previous step, this project will be largely restricted to data collected from evidence-based design, factual descriptive data such as sizing and codified constraints.

Analyze. Findings will be identified from both raw data and summary studies. Where possible, such findings will be ranked according to importance to stakeholder groups to establish clear guidelines for future design research.

\section{Evidence-based Design as a Resource}

The Center for Health Design describes evidence-based design as a system that bases decisions on credible research which will produce solutions that demonstrate improvements in the organization's outcomes, economic performance, productivity, customer satisfaction, and cultural measures. Established in 2000, healthcare providers and the Center for Health Design collaborated to employ evidence-based design as part of their design research methodology for future projects (The Center for Health Design, 
2010). The most accurate data comes from analyzing evidence from current physical conditions that show how patients, staff, and the general public are affected. A series of case studies that have created benchmarks in the design world, have come from a program known as the "Pebble Project" which is overseen by the Center for Health Design. These projects document current healthcare facilities and their clinical performance, patient and family satisfaction, organizational change, and finance. Pebble Project studies are usually at the forefront of healthcare design. Professionals look to those resources for reliable data to improve design (The Center for Health Design, 2011). The [Pebble Project] will invoke evidence-based design as a resource in the design process to help identify issues that will need addressed in the future (The Center for Health Design, 2010).

\section{Design Process with Evidence-Based Data}

Combining the design process with evidence-based data allows researchers and designers to address all three cultures of human knowledge equally to achieve the ultimate design solution for a project. The design process invokes designerly ways of knowing as the overarching framework to solve the problem. It provides a strategy to identify problems, barriers, constraints, and criteria important to solving the targeted problem. Evidence-based design applies familiar research methods favored by science and the humanities as a means of attaining the quality data to further inform the solution. It provides strategies and tactics that have been proven to be effective to provide a reputable foundation for balanced right-and-left-brained conceptual solutions. Chapter Five will return to "Phase 2: Synthesis" of the design process to explore opportunities for further research. 


\section{CHAPTER FOUR: FINDINGS}

Chapters One and Two of this document addressed the first stages of the design process by "committing" to engage the problem of providing periodic cancer treatment to underserved populations in rural West Virginia. We explored the situation in terms of relevant factors including cancer causes, mountainous terrain, advancing age, and lower income. Then we "stated" the objective of meeting that need for access to cancer treatment through a mobile cancer care unit. Chapter Three presented the method by which we might establish the feasibility of the project. That brings us to the current chapter, which presents the "collected" findings of this research. Since this research is meant to be translational (i.e. to guide professional practice), the findings are presented in the order that they would be considered in a design project, from broad to specific.

\section{Mobile Unit}

Size and configuration are perhaps the first considerations in any interior design project. The context for this project is a 74' long tractor-trailer combination with retractable side extensions (see Figure 4.1). 


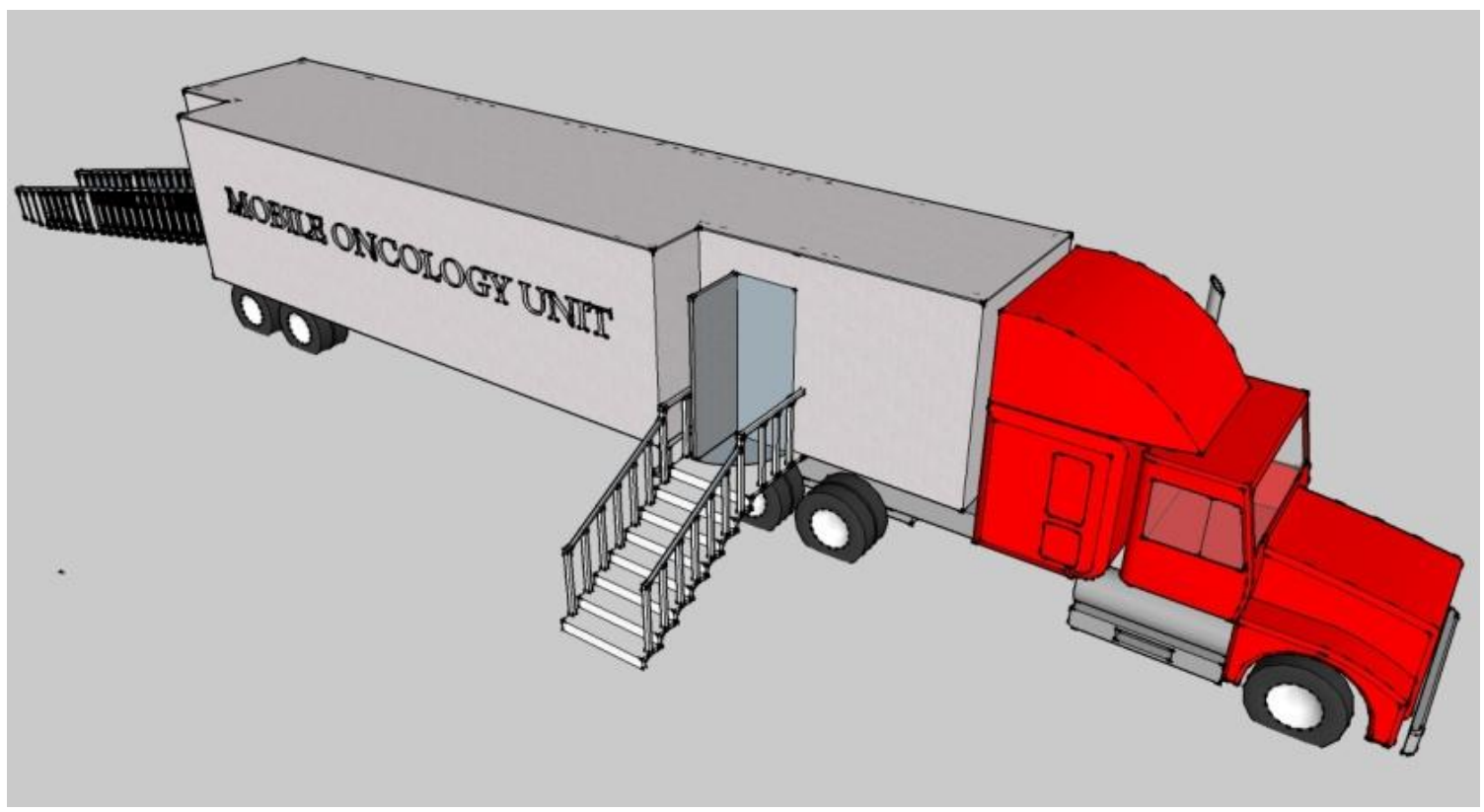

Figure 4.1. Conceptual mobile oncology unit.

The unit gets 5 miles per gallon and uses diesel fuel. It offers the capability of running cable from trailer to tractor for satellite, phone, and internet capabilities. There is also provision for a refrigerator on board. A similar unit currently in use by the Shakopee Mdewakanton Sioux boasts the following dimensions (See Table 4.1).

Table 4.1.

Size/Weight Specifications for a Comparable Mobile Unit.

\begin{tabular}{|l|l|l|}
\hline Trailer & & \\
\hline & Length & 53 feet \\
\hline & Width & 8 feet 6 inches \\
\hline & Width with sides out & 12 feet 4 inches \\
\hline & Height & 13 feet \\
\hline & Weight & 40,280 pounds \\
\hline & & \\
\hline
\end{tabular}


Continued- Table 4.1.

Size/Weight Specifications for a Comparable Mobile Unit.

\begin{tabular}{|l|l|l|}
\hline $\begin{array}{l}\text { Tractor/trailer } \\
\text { combined }\end{array}$ & & \\
\hline & Length & 80 feet \\
\hline & Length with overhang & 74 feet \\
\hline & Width & 8 feet 6 inches \\
\hline & Width with sides out & 12 feet 4 inches \\
\hline & Height & 13 feet 6 inches \\
\hline & Weight & 57,280 pounds \\
\hline
\end{tabular}

Note. Adapted from "The Multi-Functional mobile Medical Unit Fact Sheet" by Shakopee Mdewakanton Sioux Community, 2009.

Mobile units of this type are available from Lifeline Mobile, Medical Coaches,

Startracks, Farber Specialty Vehicles, and MSV Global among others (LifeLineMobile, 2011; Medical Coaches, 2011; Medical Coaches, 2008; Medical Coaches, 2004; Farber Specialty Vehicles, 2011). A dimensioned drawing is provided in Figure 4.2 below for rough planning purposes.

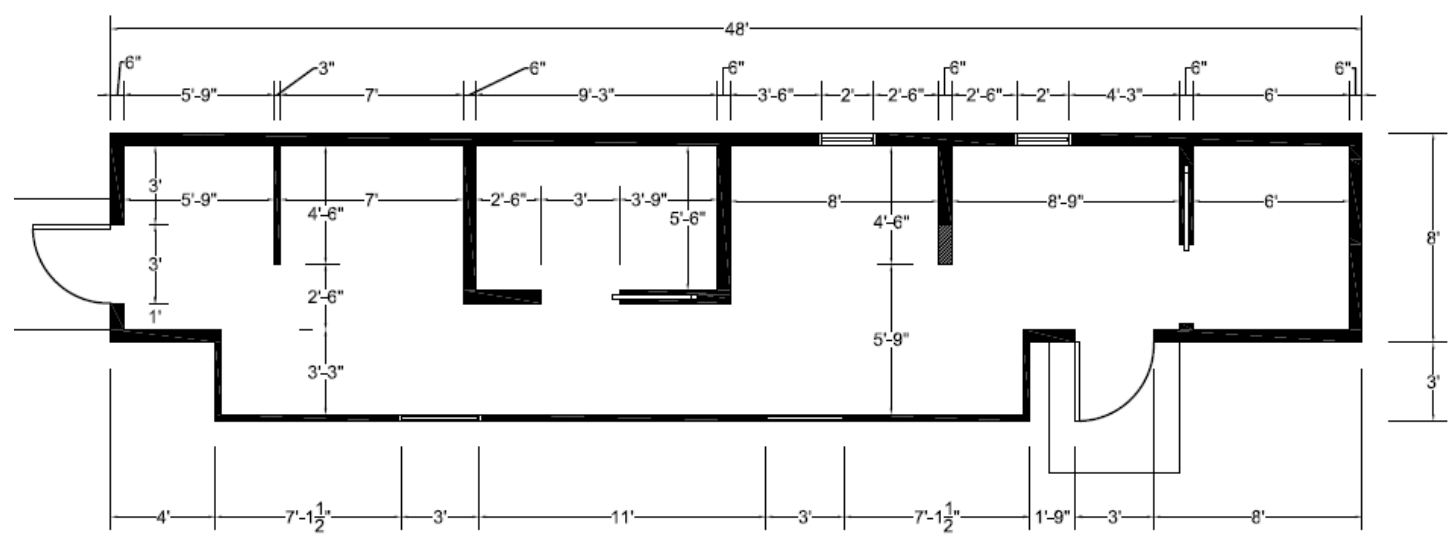

Figure 4.2. Dimensioned drawing of a conceptual open-plan trailer space.

Note. Room size and placement is arbitrary in this drawing and easily repositioned. Partitions are indicated solely to illustrate potentials within the space. 


\section{Ambulatory Care}

To properly design, specify and evaluate options available in these healthcare offerings, it is necessary to know more about which considerations are important, and to whom. In the literature of Evidence-based Design, mobile units such as these would fall under the broad umbrella of Ambulatory Care as opposed to hospitals or long-term care facilities. Between the months of June and September of 2007, Project Principal Uriel Cohen, Co-Principal David Allison, and Survey Research Consultant James Witte conducted a survey to identify what were the most critical issues in healthcare environments. The survey was distributed to 639 individuals that were divided into 15 different stakeholder groups. The surveyed were then asked to select one of three types of environments (Ambulatory, 103 respondents; Hospitals, 443 respondents; and Long-term Care, 93 respondents) and answer a series of questions unique to the selected environment. The most important question this survey was, "What is the most critical issue in health care environments?" (Cohen, Allison, \& Witte, 2009; see Table 4.2). Specific patient care and public areas were targeted. The surveyed were asked to rank their answers as the lowest number 1, equaling "Not Problematic" and the highest number, usually 5, would indicate "Very Problematic". 
Table 4.2

Areas of Concern within an Ambulatory Care Facilities

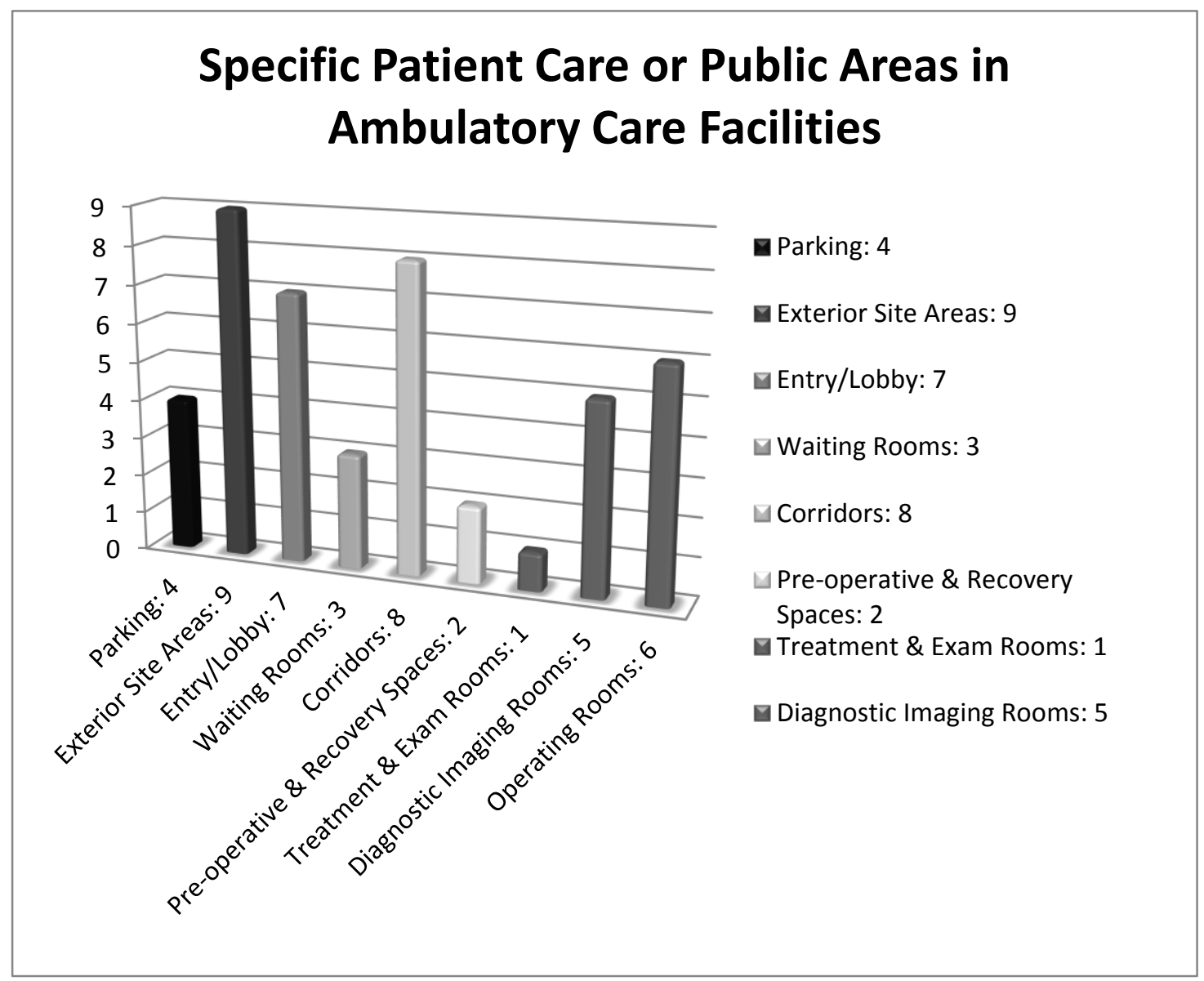

Note. Adapted From: "Critical Issues in healthcare Environments," by U. Cohen, D. Allison, and J. Witte, 2009, p. 40. Copyright 2009 by The Center for health Design.

Once the problematic areas were identified, the surveyed were asked to answer questions pertaining to patient care problems (see Table 4.3). In order of importance, falls, recovery rates, facility acquired infections, pain control and medication and treatment errors were targeted for attention. 
Table 4.3.

Concern and Considerations for Patients and their Care in Ambulatory Care Facilities

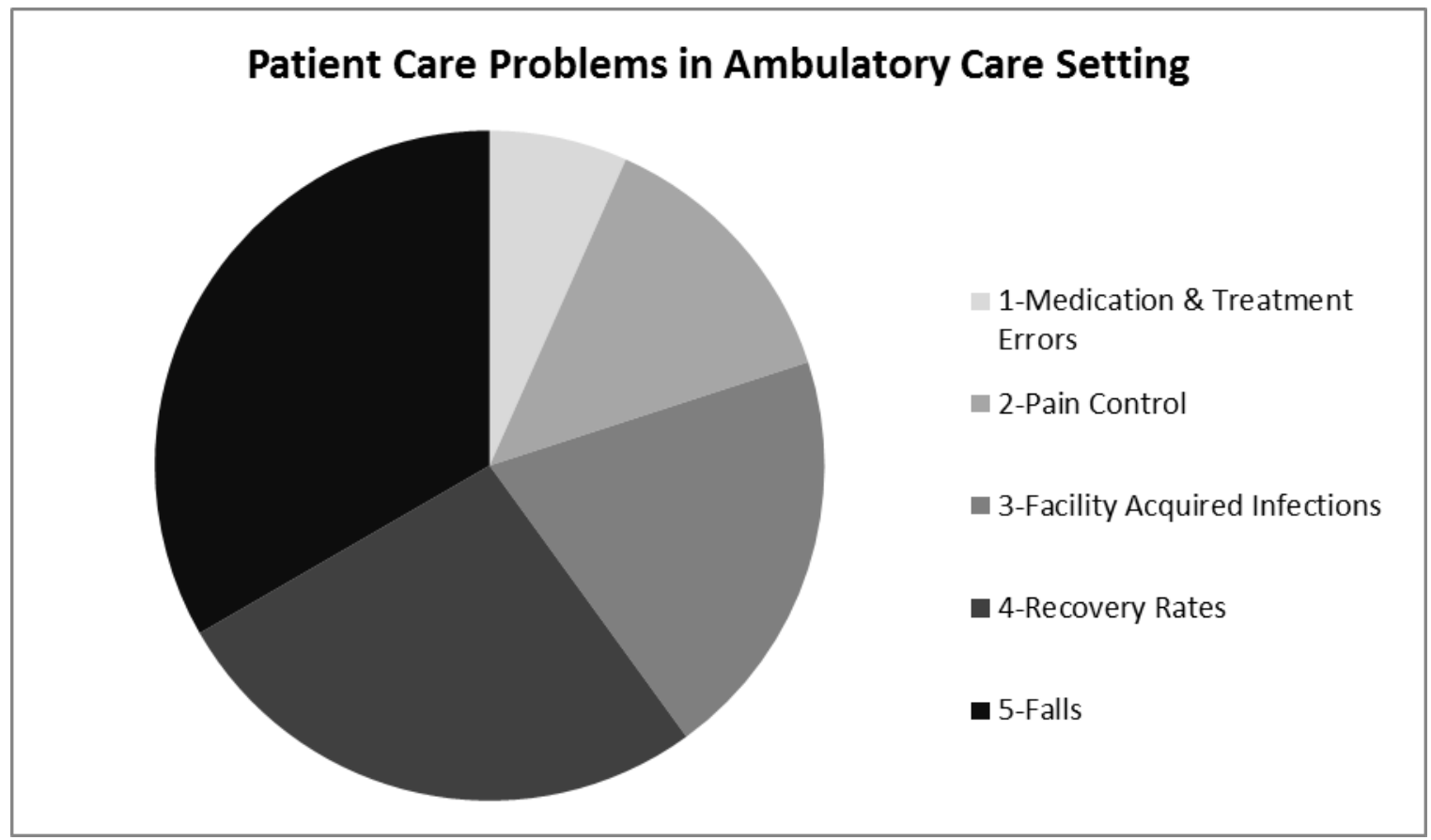

Note. Adapted From: "Critical Issues in healthcare Environments," by U. Cohen, D. Allison, and J. Witte, 2009, p. 40. Copyright 2009 by The Center for health Design.

Falls. Falls are a common insufficiently documented event that occurs in hospital and many other settings. Falls are categorized into two types, personal (physiological) and environmental (type and condition). Five aspects need attention when addressing the problem of falls:

1. health and physical condition of the fallen

2. risk of fall reoccurrence

3. immediate and long term costs associated with a fall

4. levels of lighting

5. types of floors 
Often researchers do not include description of the environmental conditions surrounding the fall, which increases the difficulty in determining the actual role of the built environment around the event (Gulwadi, Calkins, 2008). Existing evidence-based design research suggests improving lighting conditions and securing carpeting may contribute to the prevention of falls but there is actually no clear evidence of the effectiveness for independent modification programs on the environment (Chang, Rubensteing, and Mojica, 2004). One study (Brandis, 1999) found that falls occur mostly in bedrooms and bathrooms. Problems included slippery floors, inappropriate door openings, poor placement of rails and accessories, and inappropriate heights of toilets and furniture. A fall-prevention program was subsequently implemented to identify high-risk patients, enhance management strategies, modify environments and equipment, and increase standardization. The program resulted in an overall decrease in falls by $17.3 \%$, a decrease of falls resulting from transfers to and from beds by $42.2 \%$, and a decrease of falls resulting from transfers during toileting by $16.1 \%$ (Brandis, 1999). Better documentation and research about the built environment is necessary for designers to help with fall prevention.

Recovery rates. One predictor of patient's recovery rates is their response to the environment (Harris, McBride, Ross, and Curtis, 2002). Research indicates that the speed of recovery increases by establishing an enjoyable space that is comfortable and aesthetically pleasing. Color, artwork, adequate lighting, sun-lighting, and natural views are major contributors to patient satisfaction. Patient satisfaction and recovery rates are synonymous. Patients reported a shorter and more satisfactory stay when small changes were made to the general layout, color scheme, furniture, and floor covering (Leather, 
Beale, Santos, Watts, and Lee, 2003). Additionally, spaces that are private, quiet, have a comfortable temperature, allow easy access to everything in a room, have a working television, comfortable bed, accessible bathroom, provide a sense of control, and are easy to clean have been found to affect the patient's rate of recovery (Press Ganey Inc., 2007). Overall simple aesthetical changes to a space were reported to have major impacts on a patient's satisfaction and recovery during their stay at a medical facility.

Facility acquired infections. Facility acquired infections are a leading cause of death. To prevent these occurrences, the Center for Disease Control (CDC) and the Healthcare Infection Control Practices Advisory Committee (HICPAC) set up standards for facilities to follow. There are three transmission routes for infections: airborne, contact, and water (droplet). Installing high-efficiency particulate air (HEPA) filters provide effective ventilation protection against airborne pathogens and installing barriers between patient care areas and properly sealing patient windows will help patients avoid acquiring infections through contact or water routes. Research has indicated that employing proper cleaning and disinfection procedures along with easy-to-clean floor, wall, furniture coverings, and installing automated technology for hand washing and/or alcohol-based hand-rub dispensers at beside and other accessible locations will help prevent transmission of germs (Ulrich, Zimring, Zhu, DuBose, Bo Seo, Seon Choi, Quan,, and Joseph, 2008).

Researchers recently studied the use of carpeting versus other floor coverings and the results were inconclusive. Scientist found that certain contact pathogens like Vancomycin-Resistant Enterocci (VRE) survive less well or for shorter lengths of time 
on carpet than on other floor coverings like rubber tile, linoleum, vinyl sheet goods, and vinyl compositions. The research also found that carpeting transferred less VRE to hands than the rest of the previously mentioned flooring and performed as well in cleaning as any other floor covering tested (Lankford, Collins, Youngberg, and Noskin, 2006). Studies are showing a variance in beliefs about whether or not carpet is suitable for medical facilities and it is expected to remain a controversial issue (Harris, 2000).

Antimicrobial products have been in development for years and as time passes, more companies have been coming up with new technology for a variety of uses. Nature inspired product lines with disinfectant properties are accessible to designers and will foster an environment to discourage healthcare facility acquired infections and promote healing. Broadloom or solution-dyed nylon tiled carpeting that has been treated with an antimicrobial solution is available in a variety of colors, patterns, and designs.

Commercial floorings like Acczent vinyl flooring from Johnsonite, provides low maintenance, high performance, and with the look of wood or Mondo's Harmoni floorings that contributes to LEED points are stain resistant, naturally antibacterial and antimicrobial, provide cushion, and have a low life-cycle cost are other options. Aside from flooring, pvc-free upholstery and upholstery that has been treated by BioAm antimicrobial technology with a Nano-Tex recycled finished is available for privacy curtains and other upholstered surfaces. Companies like STA-CARE, INC., manufacture solid surface bathroom systems with antimicrobial properties. The company incorporates an additive called Polygiene in its resin because of its abilities to prevent mold, mildew, and odor causing bacteria. Advancements in product technology aid in man-made 
precautions and standards that are already set by the CDC and HICPAC (Vendome Group, LLC, 2008).

Pain control. Pain is a pervasive and serious problem in the medical field and evidence-based medical research and evidence-based design research has found that exposing patients to nature in clinical settings has substantially alleviated pain (Malenbaum, Keefe, Williams, Ulrich, and Somers, 2008; Ulrich et al., 1993). Patients that had large windows providing sunny well-lighted views of nature or were in in a spatially open area with pictures of trees and water needed fewer doses of strong pain drugs than patients exposed to abstract images or in a control group with no picture (Ulrich et al., 1993). Visual art such as paintings, prints, and photographs depicting nature or nature videotapes accompanied by music lessened pain, anxiety, and stress for patients (Malenbaum et al., 2008; Miller, Hickman, \& Lemasters, 1992). Ceiling mounted nature views (see Figure 4.3 below) were also reported to lessen pain (Diette, Lechtzin, Haponik, Derrotes, \& Rubin, 2003). 


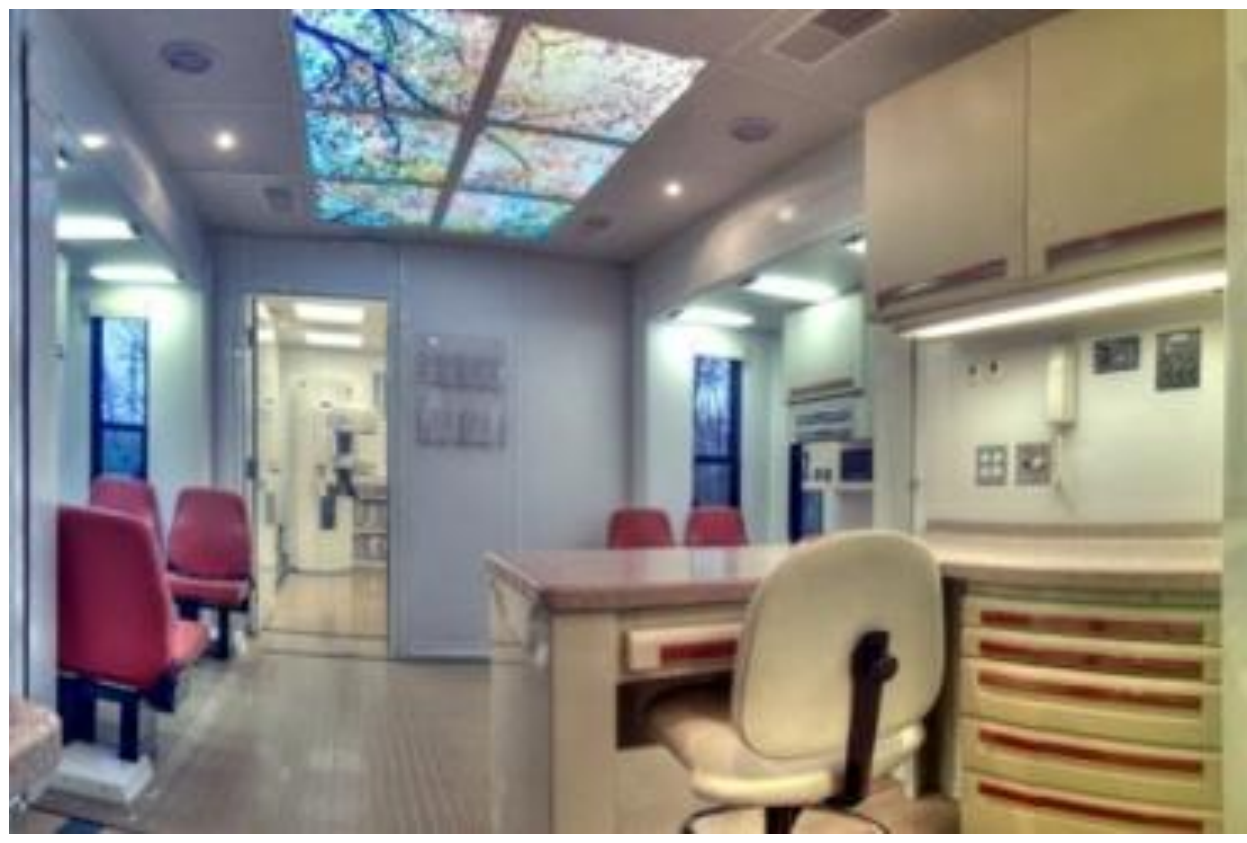

Figure 4.3. Ceiling mounted nature view from Lifeline's Mobile Unit helps bring a sense of nature into a space while acting as a distraction from discomfort or any pain. From “LifeLine’s Mobile Unit Gallery” by LifeLineMobile, 2011. Copyright 2011 LifeLineMobile.

Medication and treatment errors. Medical errors were found to be the result of (a) latent conditions created by management that included work overload, staff shortage, and inexperience with working conditions and (b) design factors such as noise, lack of space, and other design failures. Loud noises can distract care providers and generally have a negative impact on the providers and patients (Malenbaum et al., 2008). Other design factors that have been shown to influence the quality of care besides noise are light and acuity adaptability (Flynn et al., 1999; Kistner, Keith Sergeant, and Hokanson, 1994). One study showed lower rates of medical errors when lighting levels for work surfaces is high (Buchanan, Baker, Gibson, Jiang, and Pearson, 1991). Beyond these factors, more research into environmental factors needs conducted to improve spaces. 
User satisfaction problems were the next to be examined (see Table 4.4.).

Interestingly, social contact ranked well above privacy in importance. Children, family and visitor accommodations trumped the needs of the disabled, elderly and staff members. Emotional contact, cultural sensitivity and confidentiality were highly valued. 
Table 4.4.

Levels of Satisfaction among Users in Ambulatory Care Facilities

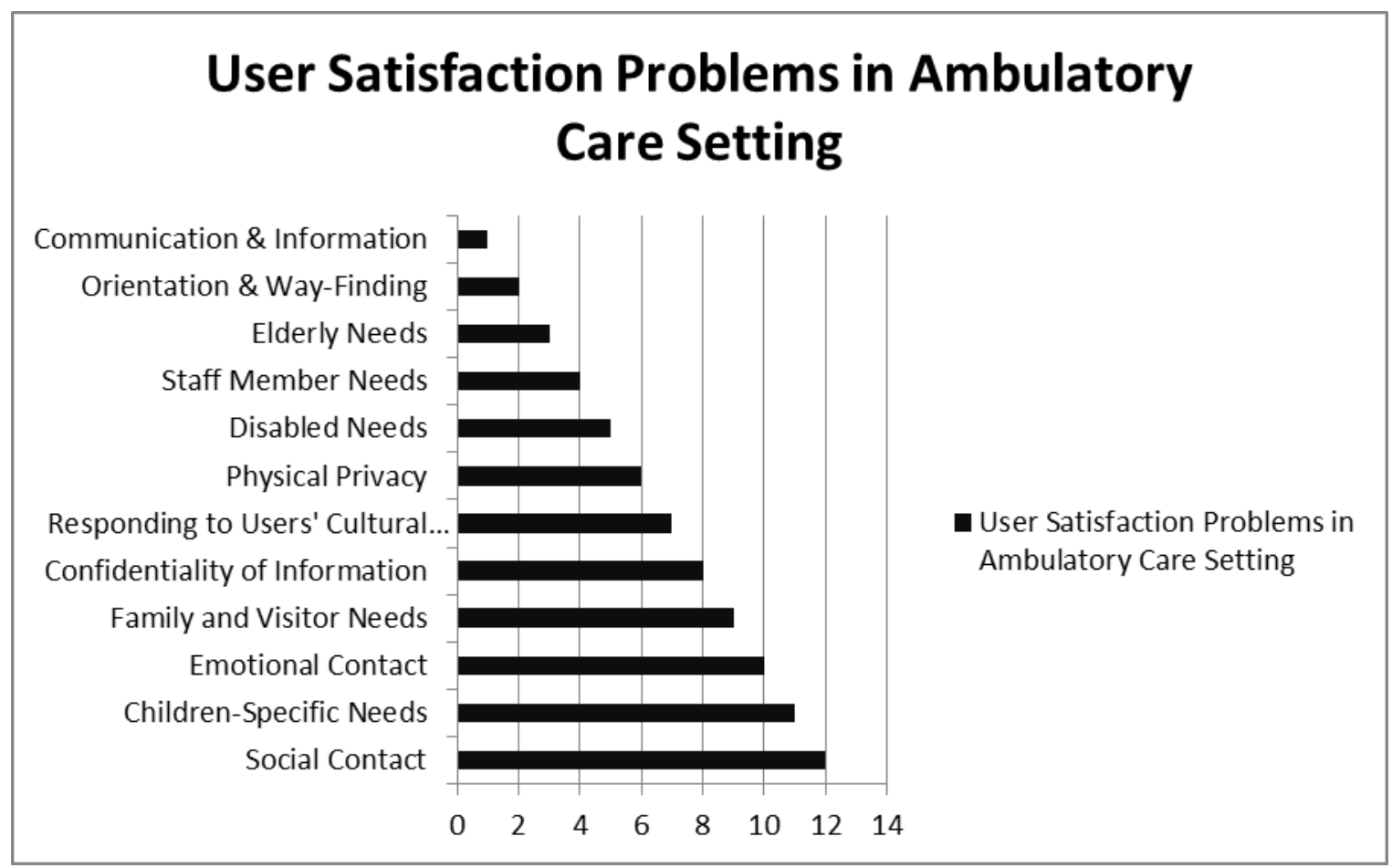

Note. Adapted From: "Critical Issues in healthcare Environments," by U. Cohen, D. Allison, and J. Witte, 2009, p. 40. Copyright 2009 by The Center for health Design.

Social contact. Medical staff, families, and friends have an integral role in the social support a patient needs throughout the healing process. Touching, talking, surveillance, or the mere presence of someone involved with providing care or support has been shown to help patients deal with their medical treatments (Ulrich et al., 2008).

There has been some evidence linking design features to the amount and quality of social support a patient receives within single bed rooms (Chaudhury, Mahmood, and Valente, 2003; Sallstrom, Sandman, and Norberg, 1987). Privacy provided by single bed patient care rooms encourages family visits and social interactions as long as the space is accommodating to the visitors. To ensure this interaction can occur, spaces should include appropriate family zone and comfortable furniture to promote longer visitations 
which ultimately could foster the social contact patients rely on (Ulrich et al., 2008).

Research indicates that other spaces such as lounges, day rooms, and waiting rooms that also have comfortable, moveable furniture to allow flexible arrangements and groupings stimulate social interactions (Holahan, 1972; Melin and Gotestam, 1981; Peterson, Knapp, and Rosen, 1977; Sommer and Ross, 1958).

In an attempt to add to the growing knowledge in evidence-based design in 2006, Karin Dijkstra MSC, Marcel Pieterse MPH PhD, and Ad Pruyn PhD conducted studies on patients and the findings supported the claims made by other studies and articles. The arrangement of seating can determine the amount of socialization that will occur. A study set up two different arrangements, an unstructured arrangement and a mixed arrangement. It was observed that the group sitting in the mixed arrangement seating was more social and more personal interaction happened whereas the unstructured arrangement had a discouraging effect on socialization and interaction (Holahan, 1972).

Design decisions where the use of carpeting instead of vinyl floors in patient rooms has coincided with an increase of a family's length of stay. Such decisions should be made after comprehensive research and consideration that includes the impact it would have on infection control and cleaning are exhausted (Harris, 2000). The evidence from the research points towards environments that provide privacy, comfort, and flexibility, not necessarily in that order, advocate social support and interaction.

Children-specific needs. A study conducted in 2006 researched the art preferences of schoolchildren and hospitalized pediatric patients. Results of the study indicated that age, gender, or health status did not produce a variety of preferences. All participants 
preferred nature art or scenic images over abstract and cartoon-like pictures (Eisen, 2006).

When research was conducted to find out what all stakeholders in children's healthcare wanted, designers quickly found that pleasing everyone would not be plausible by using the conventional approach of asking the simple question of "What do you want in the space?" Rather, the designers used the Three Cultures of Human Knowledge to find the best design solution. By asking stakeholders "What is your current experience?" and "What does it mean to you?" (and asking them to answer through the use of collages), they uncovered four underlying themes to consider when designing a space that would “make it better" for stakeholders in children's healthcare: transformation, control, connection, and energy.

Transformation was the most important theme to all of the stakeholders who were interviewed, including families, patients, medical staff, etc. The previous space that these stakeholders were exposed too left them feeling unbalanced and transformation into a balanced stated was desired. The other themes supported the transformation: stakeholders wanted a sense of control over their surrounding environment, a connection to the outside world and with others, and energy to get them through the medical experience and journey (Carpenter, 2009).

In response, design elements employed at Children's Hospital in Pittsburgh, Pennsylvania created a "home-like environment" through the use of bright colors in hallways, wood floors, tactfully placed lighting that ranged in from soft to focus or playful. Windows provided views to the exterior as well as between interior spaces, 
which allowed parents and children to see staff, other patients, and families and know that they are not alone in their journey. Patients can control the shades of the windows to determine their privacy level (see Figure 4.4.).

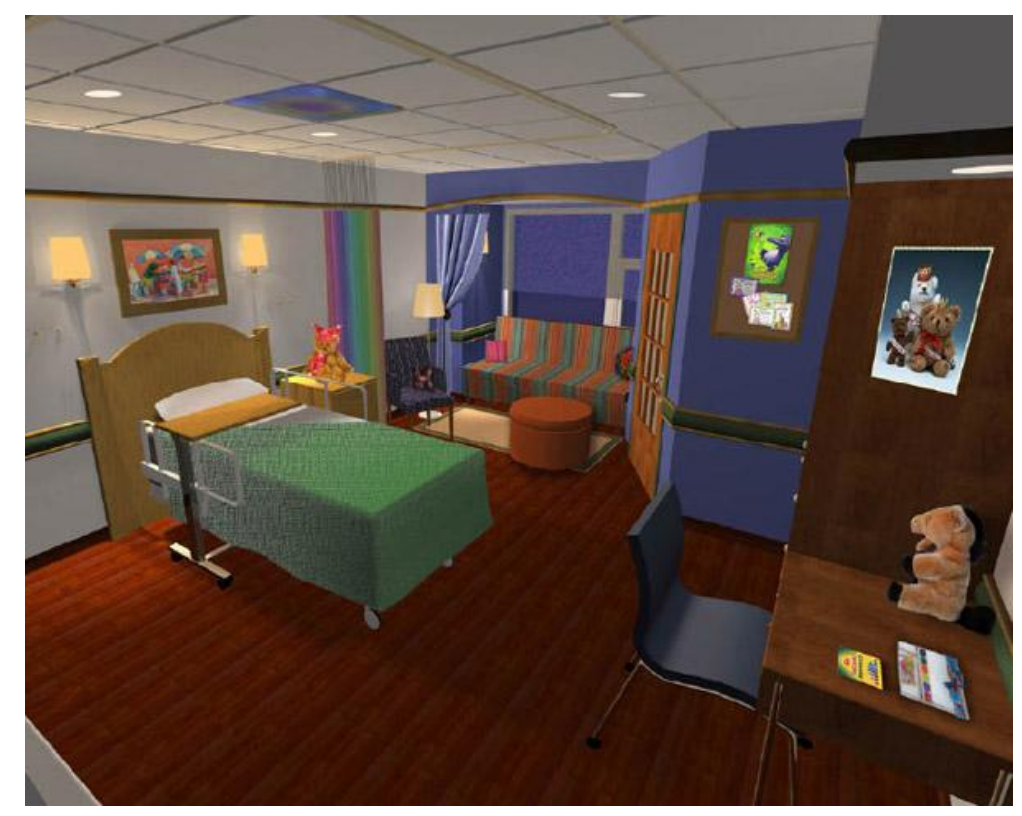

Figure 4.4. Conceptual single-bed pediatric care room for Children's Hospital of Pittsburgh of UPMC. Adapted from "Building for the Future", by University of Pittsburgh Medical Center, 2011. Children's Hospital of Pittsburgh of UPMC. Copyright 2011 by University of Pittsburgh Medical Center.

Regarding the topic of windows, the studies conducted by Dijkstra, Pieterse, and Pruyn were focused on determining the effects of a patient's health and well-being with the presence of windows. A factor taken into consideration when performing the study was what was seen through these ports. The results showed a positive effect when windows with a natural view were available. Clinically windows provided positive outcomes for patients with delirium issues, sleep issues, and shorten the length of stay. When patients were given access to sunlight, findings showed positive effects on the length of stay, mortality rate, pain, and stress (Dijkstra, Pieterse, and Pruyn, 2006). 
Beyond design elements, designers hid the medical equipment in patient rooms and mounted shelves for toys, books, DVD's, and projects. Parents were given access to pantries to store snacks or any food while they were there. Designers created designated areas with appropriate furniture to complete projects or access the internet.

Emotional contact. When individuals go through any kind of medical journey, they can encounter expected and unexpected changes or stressful event may increase the need for emotional support and contact (Tarkka, Paavilainen, Lehti, and Astedt-Kurki, 2003). Emotional contact and social contact are very closely related, for they both encourage healing and come from care providers, family, and friends, significant others, online support groups, networks, and even strangers. When a patient receives emotional contact, research has indicated that it reduces stress and improves a patient's physiological outcome. Emotional contact is not only for patients, but for families as well and when they acquire this support, it has a positive influence on everyone involved in the process (Kaunonen et al., 1999; Koivula, Tarkka et al., 2002; McMurray, 1998; Tarkka, et al., 2003).

Professionally informed and targeted emotional support may be required for both patients and other stakeholders. Professional counseling, print materials and/or other media information can provide significant guidance in a difficult time. As an example, in the case of a child's illness the professionals at Doernbecher Children's Hospital counsel the following in support for siblings:

Your child's illness or hospitalization impacts the entire family. How brothers and sisters respond to this situation can vary greatly with each child. 
Your child's siblings may feel:

- Guilt that their sibling's sickness is somehow their fault. For example, "if I hadn't gotten into a fight with my brother, he wouldn't have gotten sick."

- Jealousy because the sick sibling is getting a lot of attention and/or gifts.

- Anger or acting out at schoolmates, at their sick sibling or others.

- Worry or fear that they may catch the illness or get sick.

- Loneliness or feeling left out of the hospital experience and the daily family routines.

- Sadness causing them to avoid some of their normal activities.

What you can do to help:

- Explain why your hospitalized child is in the hospital in terms their sibling can understand. Clarify that they did not cause the illness or problem.

- Encourage your child to visit the hospital when possible. Talk with our child life specialists about how to prepare your child for the visit.

- Encourage your child to ask questions or concerns they may have.

- Give your child ways to express themselves, such as drawing pictures, writing in a journal or being physically active.

- Spend time with your child, even if it is a short time. For example, call them from the hospital and do their bedtime ritual over the phone, and attend their games or other events.

- Identify a trusted adult your child can talk to.

- Encourage your child to go to school and keep as normal a routine as possible. Family and visitor needs. Evidence-based research is showing that single patient rooms have the largest potential to have the greatest number of outcomes. A single patient room provides family and visitors with privacy that promotes longer visits. Appropriate family zones within a room help define its use to the user and create a sense of welcome and belonging. Families generally receive support from healthcare professions, other family members, friends, other families, networks, and support groups. 
Finding these outlets allows the families to grieve properly and helps them to provide better support to the patient. Areas within medical facilities besides patients' rooms that foster support for non-patients are in areas that are more public like lounges, waiting rooms, conference rooms, or other spaces that have comfortable furniture that is also flexible and can be rearranged to suit their needs (Ulrich et al., 2008).

Confidentiality of information. A patients' protection of confidentiality and privacy is written into the United States law through the Health Insurance Portability and Accountability Act (HIPPA). The American Medical Association has also written a Code of Medical Ethics that ensures patient confidentiality. The intent of the code of ethics is to build trust between patient and physicians so that they will provide full disclosure which will let physicians to properly and accurately diagnose patients (American Medical Association [AMA], 2011). When HIPPA guidelines and procedures are not followed, a patients' privacy is risked, which can lower their overall satisfaction (Barlas, Sama, Ward, and Lesser, 2001). When patients become dissatisfied, their overall attitude can worsen and proper healing may be hindered. Also, if a patient does not trust their healthcare provider, they may withhold vital personal information or refuse to be examined because of their concerns. This could increase acquired infections, medical errors, and improper treatment (Barlas et al., 2001). Dissatisfaction can also be caused by a breach of confidentiality which occurs when information is disclosed to a third party without consent of the patient via verbal, written, telephone, fax, email, or electronic mediums. More recently, healthcare facilities have been changing how they keep medical records to prevent breaches of confidentiality. A transition from paper and charts to electronic files is allowing physicians and medical staff to access a patient's files from 
any location at any given time but also helps protect patient's information because individual medical files require clearances and are password protected (AMA, 2011).

Users' cultural expectations. To meet users' cultural expectations, a designer must create an environment that is sensitive of peoples' lifestyles and be accessible to any cultural groups or persons' needs. A space designed around cultural expectations will create a "sense of place" and improve the effectiveness of the treatment on the user. One way to achieve cultural sensitivity is to create a space that is adaptable (Surrenti, 2009). Adaptable, coming from the root word "adapt", is defined as to make fit (as for new use) often by modification or adapt could mean an implementation of a modification according to changing circumstances (Merriam-Webster, 2011a). An adaptable interior space could refer to a space that is multifunctional. An adaptable exterior could make reference to an innovation or cultural movement such as sustainable buildings which are buildings that use resources in a manner that ultimately does not deplete or permanently leave the resources damaged (Merriam-Webster 2011c). The architectural industry has been trying to keep up with standards, new cultural trends, and expectations that people have expressed an interest in making facilities environmentally friendly while having them reduce $\mathrm{CO} 2$ emissions (see Table 4.5.). 
Table 4.5.

Concerns of Users' towards Environmental Issues for Ambulatory Care Spaces

\section{Environmental Issues in Ambulatory Care Facilities}

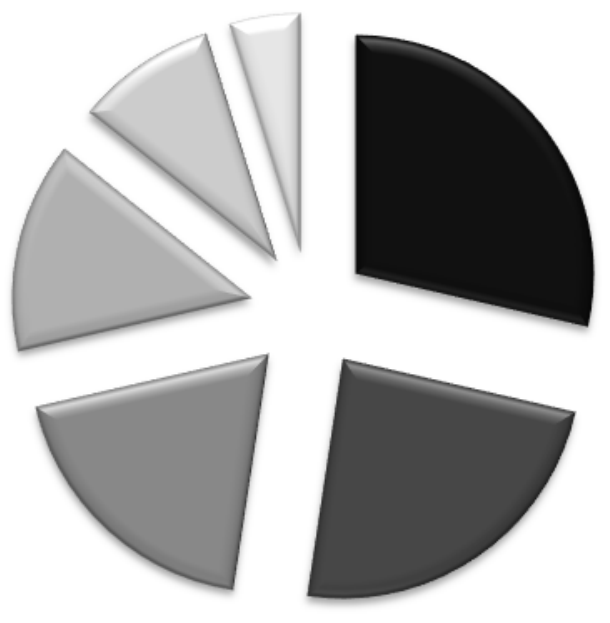

a 6-Water Management

5-Solid Waste

Management

a-Toxic Materials Management

3-Energy \& Power Management

2-Use of Renewable Building Materials

$\square$ 1-Improving Indoor Air Quality

Note. Adapted From: "Critical Issues in healthcare Environments," by U. Cohen, D. Allison, and J. Witte, 2009, p. 40. Copyright 2009 by The Center for health Design.

Cohen and his associates found interest (in order of importance) in change involving: medical procedures and practices, regulation, reimbursement, medical culture, medical technology, and rapid change in information technologies (see Table 4.6.). 
Table 4.6.

Adaptability of Ambulatory Care Facilities

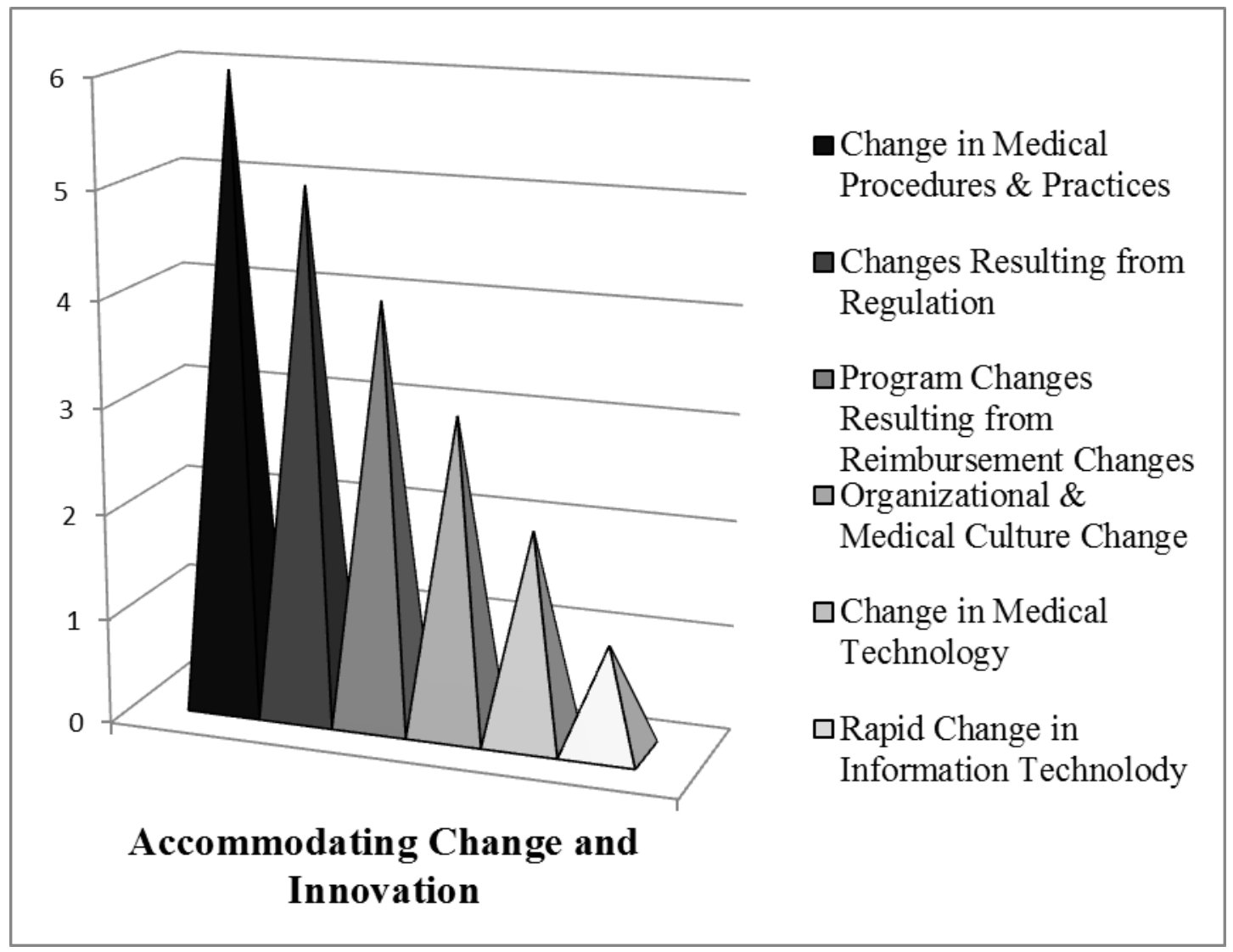

Note. Adapted From: "Critical Issues in healthcare Environments," by U. Cohen, D. Allison, and J. Witte, 2009, p. 40. Copyright 2009 by The Center for health Design.

The development of medicine and healthcare equipment occurs rapidly and a space is more cost efficient when that space is flexible and can easily adapt to these changes. We are currently in a time of massive federal reconsideration of all aspects of the healthcare system. It will be some time before the full impacts of recent and proposed changes are known. Using modular and flexible components will create a space that is capable of adapting to new trends (Eggen 2008). This ability will ultimately justify the expense of creating a design that supports flexibility because it will make the space or 
facility more cost efficient over time rather than remodeling ever 10 years (Zeidler, 2005).

Physical privacy. Privacy is something that is very valuable to patients. Single bed or private rooms are ideal for any type of treatment because the chance for acquired infections from a roommate significantly decreases and has the greatest number of positive outcomes. There is strong evidence that private rooms reduce medical errors, patient falls, pain, patient stress, depression, length of stay, improve privacy and confidentiality, improve communication, improved social support, and increased patient satisfaction. Any sound-absorbing materials incorporated into the design will reduce breaches in patient's privacy. Hard walls provide better privacy but do not allow for the same flexibility as spaces defined with curtains, so decisions about what type of walls to use should consider the use of the space, the information that will transpire within the space and the rest of these considerations discussed within this chapter (Ulrich et al., 2008).

Disabled needs. Design concerns and issues regarding those individuals with disabilities are generally addressed by following guidelines set forth by the American's with Disabilities Act (ADA) as well as provisions in The Guidelines for Design and Construction of Healthcare Facilities, the Facilities Guidelines Institute (FGI), the International Building Codes (IBC), and the Joint Commission on Accreditation on Healthcare Organizations (JCAHO) to promote design initiatives that go beyond standard construction requirements by law. 
These standards, codes, rules, and regulations help a designer to create a space with a universal design. Universal design or "universal access" is defined by the Joint Commission on Accreditation of Healthcare Organizations (JCAHO) as a concept that, when applied to environments, ensures the facilities, products, and services are useable by all (see Table 4.7.).

Table 4.7.

Principles to Guide Designers to Build Universally Accessible Space

\begin{tabular}{|l|l|}
\hline \multicolumn{2}{|c|}{ Seven Principles of Universal Design } \\
\hline Equitable use & $\begin{array}{l}\text { The design must be useful to people with a } \\
\text { variety of abilities }\end{array}$ \\
\hline Flexibility in use & $\begin{array}{l}\text { The design meets the needs (preferences and } \\
\text { abilities) of a diverse group of people. }\end{array}$ \\
\hline Simple and intuitive use & $\begin{array}{l}\text { Regardless of the user's experience, } \\
\text { knowledge, language abilities, and level of } \\
\text { concentration, the design is easy to understand. }\end{array}$ \\
\hline Perceptible information & $\begin{array}{l}\text { Regardless of external conditions, the design } \\
\text { must effectively communicate necessary } \\
\text { information. }\end{array}$ \\
\hline Tolerance for error & $\begin{array}{l}\text { The design has minimal hazards and any } \\
\text { repercussions for any unforeseen occurrences } \\
\text { are minimized by the design. }\end{array}$ \\
\hline Low physical effort & The design is efficient and easily utilized. \\
\hline Size and space for approach and use & $\begin{array}{l}\text { Regardless of body type or circumstances, a } \\
\text { suitable allowance for approach, reach, } \\
\text { manipulation, and use is required. }\end{array}$ \\
\hline
\end{tabular}

Note. Adapted from "Universal Design for Health Care Facilities: Addressing Safety, Access to Care for a Diverse Patient Population," by Joint Commission on Accreditation of Healthcare Organizations, 2009. Environment of Care News, p. 11. Copyright 2011 Joint Commission on Accreditation of Healthcare Organizations.

The Joint Commission's senior vice president, Paul Schyve, M.D. says, "Universal design complements a patient-centered approach to care because it is a concept driven by understanding the individual patient's experience of care." Addressing 
design problems for those who have a condition that makes normal tasks more challenging will make their healthcare experience more relaxing and enjoyable. Major renovations are not always necessary to make these improvements. Adjustments in counter heights, improved positioning of magazine racks in waiting areas, removal of hazardous or protruding objects in spaces, and grab bars in bathroom spaces can impact the overall experience in a healthcare space. Also providing a variety of seating (i.e. armed chairs, armless chairs, etc.) is a simple way to make a space user-friendly. As universal access is integrated into designs, the benefits are seemingly piling up. Time will expose where more problems exist, and as we all age, we may develop conditions that will make certain routines challenging, but the universally designed buildings should not be one of those barriers (Joint Commission on Accreditation of Healthcare Organizations [JCAHO], 2009).

Staff member needs. The design of work environments also needs to support employees. A successful design creates a space that reduces associated job stress, reduces absenteeism, and lowers staff turnover. When an environment is safe and friendly, employees feel valued, recognized, and happier. Also, a safe and friendly environment creates a positive atmosphere which can help attract and retain qualified employees to provide the best care to patients (Posada, n.d.). When a study was conducted and researchers worked with healthcare staff members to establish their needs and requirements to improve satisfaction, healthcare personnel wanted access to sufficient natural light. Workers also expressed an interest in bright focus light at workstations and sound absorbing materials to reduce noise. Reducing noise distractions and improving lighting may reduce medical errors and boost work efficiency (Ulrich et al., 2008). Other 
studies indicated that if a plan of action to prevent or lower noise levels was executed, positive effects were often concluded. The trials also found that if sound was used as a positive distracter, ambiguous results occurred (Dijkstra, Pieterse, \& Pruyn, 2006).

Improvement in work efficiency occurs when employees have quicker access to safe, user friendly, patient-related instruments. Easy access to the instrument will let care takers perform and complete tasks in a productive manner. When employees are comfortable with instruments, the patients tend to have better responses to the instruments and treatments they are receiving (Posada, n.d.). Workers also reported that single-bed rooms were less stressful than multi-bed or open-bay settings (Ulrich et al., 2008).

Elderly needs. Society has set an environment that expects individuals to function in an independent, self-sufficient level and some elderly do not feel comfortable in this type of setting, for they need assistance. As a person ages, physical and cognitive changes occur. Many adults experience changes in their mobility, changes in health, and/or a decline in visual and/or auditory abilities, which are the two most common changes associated with aging. When it comes to designing environments for the elderly and for those encountering sensory changes, it is important to equip the space to help this population regain a feeling of independence by addressing lighting levels, the use of contrasting materials, and creating a sense of control (Posada, n.d.).

A brightly lit environment helps older adults feel like they can see more and the space becomes more defined for them. Spaces that are properly lit improve the elderly's mobility and boost their confidence about the environment they are navigating. The use 
of contrasting material also provides definition for spaces and objects. To create a sense of control, placing accessible dimmer switches to allow patients to set the lighting to their own comfort level will increase satisfaction and can heighten the sense of autonomy for a patient (Posada, n.d.).

The loss of hearing is another problem patients frequently face and design needs to address these issues. Reducing background noises, high-frequency noises, and utilizing sound absorbing elements will benefit both the individual with the decline of hearing, visitors, and staff. Providing access to the main noise source or with headphones to allow an individual to adjust noise levels will help support each person's auditory capability. Healthcare environments should advocate patient control and access (Posada, n.d.).

Besides addressing lighting and auditory needs and providing a sense of control, research is showing physical and psychological improvements in patients that receive care in carpeted spaces. Patients indicated that they preferred carpet to vinyl flooring due to its comfort, noise reduction, and slip resistance attributes. Studies found older patients to walk more efficiently (have a greater step length, speed), feel more support, and confident when walking on carpet as opposed to vinyl flooring (Wilmott, 1986). Visitors were also found to have longer visitation stays in patient rooms with carpeting than vinyl flooring. These findings might suggest that carpet may improve health outcomes by fostering social support (Harris, 2000).

Orientation \& way-finding. Aligning work patterns with the physical setting through design improves efficiency, reduces waiting time, and patient satisfaction has been shown to increase (Pierce, Rogers, Sharp, \& Musulin, 1990). For nurses, walking is 
the 2 nd most frequent activity aside from passing medication and providing patient care. The layout of a space heavily influences the amount of walking that the nursing staff does. Known types that are in use now are radial, single corridor, and double corridor. Of the three types of layouts, a radial design in units has proven to be most efficient when it comes to walking for nurses but it also provides less flexibility in managing patient loads (Shepley and Davies, 2003).

When it comes to exploring medical spaces, people and patients tend to have predictable paths. To prevent confusion amongst outside visitors hospitals should have integrated systems that have coordinated elements that are visible and with easy-tounderstand signs and numbers. The signs should be clear and consistent and in a legible physical setting (Carpman and Grant, 1993). The hardest part of any medical journey should not be navigating the facility.

Communication \& Information. When the medical staff adequately communicates with family and patients and provide social support, stress and anxiety levels decrease. Along with preventing infection, providing better privacy, and less noise, single-patient rooms and private areas allow for more efficient facilitation of communication, for a there is a certain level of comfort and reduction of fear to ask questions in private settings Individuals are reluctant to share information in semiprivate patient rooms in fear of unwanted information being overheard by a roommate or their families. Also, research has shown that people feel more comfortable talking and conversing longer in private lower lighting environments (Ulrich et al., 2008). Lack of communication has been listed as a major reason why family members do not become involved in the care of patients 
and a satisfaction diminishes (Laitinen and Isola, 1996). Other reasons affecting satisfaction scores are:

1. Responses to complaints made during hospitalization or treatment.

2. Insensitivity to current health problems.

3. Staff excluding patients and family from treatment decisions.

4. Attention to emotional needs.

5. Communication, information exchange between everyone.

These concerns are major topics to address, for they can dictate a patients' entire medical journey (Engli and Kirsivali-Farmer, 1993; Mathis, 1984; Molter, 1979; Verhaeghe, Defloor, Van Zuuren, Duijnstee, and Grypdonck, 2005).

Evidence-based design has shown a strong correlation between the space and a patients' overall medical experience. The above information provided an outline of topics and considerations that need addressed followed by evidence-based design findings that have provided possible solutions or suggestions for design guidelines to improve those areas. The following table (see table 4.8.) quickly summarizes the findings and completes the "collect" portion of the design process and provides a useful resource for designers contemplating the second phase of the design process in an ambulatory healthcare venue. 
Table 4.8.

Issues in Healthcare Environments and Related Design Guidelines (as identified using Evidence-based Design).

\begin{tabular}{|c|c|c|}
\hline \multicolumn{3}{|c|}{ ISSUES IN HEALTHCARE ENVIRONMENTS } \\
\hline TOPIC & CONCERNS \& CONSIDERATIONS & DESIGN GUIDELINES \\
\hline Patient Care Issues & $\begin{array}{l}\text { In order of concern expressed: } \\
\text { Falls, recovery rates, facility acquired infections, } \\
\text { pain control, medication and treatment errors }\end{array}$ & $\begin{array}{l}\text { Falls - Pay closer attention to } \\
\text { bed and bath situations } \\
\text { Sufficient lighting } \\
\text { Non-slip flooring } \\
\text { Appropriate door } \\
\text { openings } \\
\text { Placement of bathroom } \\
\text { rails and accessories } \\
\text { Appropriate height for } \\
\text { furniture and fixtures } \\
\text { Recovery Rates - Enjoyable } \\
\text { experience speeds recovery } \\
\text { Aesthetics: Color, } \\
\text { artwork, etc. } \\
\text { Adequate lighting, sun- } \\
\text { light, natural views } \\
\text { Private and quiet } \\
\text { Comfortable temperature } \\
\text { Easy access to } \\
\text { everything in area } \\
\text { Working television } \\
\text { Comfortable bed } \\
\text { Accessible bathroom } \\
\text { Sense of control } \\
\text { Easy to clean } \\
\text { Facility Acquired Infections } \\
\text { Address three routes for } \\
\text { transmission (airborne, } \\
\text { contact, water/droplet) } \\
\text { High-efficiency } \\
\text { particulate air filters } \\
\text { additives } \\
\text { (HEPA) } \\
\text { Barriers between patient } \\
\text { care areas } \\
\text { Automated technology } \\
\text { for hand washing and/or } \\
\text { alcohol- based hand rub } \\
\text { dispensers } \\
\text { Sealing patient windows } \\
\text { Easy to clean furniture } \\
\end{array}$ \\
\hline & & Continued - \\
\hline
\end{tabular}




\begin{tabular}{|c|c|c|}
\hline TOPIC & CONCERNS \& CONSIDERATIONS & DESIGN GUIDELINES \\
\hline $\begin{array}{l}\text { Patient Care Issues } \\
\text { continued - }\end{array}$ & & $\begin{array}{l}\text { Pain Control - Nature } \\
\text { settings lessen perceived pain } \\
\text { Windows } \\
\text { Water features } \\
\text { Nature art and } \\
\text { photography } \\
\text { Nature sounds } \\
\text { Medication and Treatment } \\
\text { Errors } \\
\text { Result from conditions created } \\
\text { by management (overload and } \\
\text { inexperience) as well as } \\
\text { design factors } \\
\quad \text { Noise } \\
\text { Lighting } \\
\text { Sufficient dedicated } \\
\text { workspace }\end{array}$ \\
\hline $\begin{array}{l}\text { User Satisfaction } \\
\text { Issues }\end{array}$ & $\begin{array}{l}\text { In order of concern expressed: } \\
\text { Social contact, children-specific needs, emotional } \\
\text { contact, family and visitor needs, confidentiality of } \\
\text { information }\end{array}$ & $\begin{array}{l}\text { Social Contact } \\
\text { The presence of medical staff, } \\
\text { friends, \& family result in faster } \\
\text { recovery } \\
\text { Single bed room } \\
\text { (privacy) } \\
\text { Comfortable furniture } \\
\text { Family zones } \\
\text { Flexible furniture } \\
\text { arrangements } \\
\text { Children-Specific Needs } \\
\text { A space that is balanced, } \\
\text { connects patients to the } \\
\text { outside, \& provide a sense-of- } \\
\text { control aids the healing } \\
\text { process } \\
\text { Create a home-like } \\
\text { environment } \\
\text { Bright colors } \\
\text { Variety of lighting } \\
\text { Controllable privacy } \\
\text { shades } \\
\text { Interior \& exterior } \\
\text { windows } \\
\text { Natural views } \\
\text { Hidden medical } \\
\text { equipment } \\
\text { Easily identifiable areas } \\
\text { Comfortable furniture } \\
\text { Emotional Contact } \\
\text { Comforting place for patients, } \\
\text { families, friends, \& staff } \\
\text { Space for counseling } \\
\text { Space for print material } \\
\text { Flexible arrangement } \\
\text { Comfortable seating } \\
\text { Continued- }\end{array}$ \\
\hline
\end{tabular}




\begin{tabular}{|c|c|c|}
\hline TOPIC & CONCERNS \& CONSIDERATIONS & DESIGN GUIDELINES \\
\hline $\begin{array}{l}\text { User Satisfaction } \\
\text { Issues continued- }\end{array}$ & & 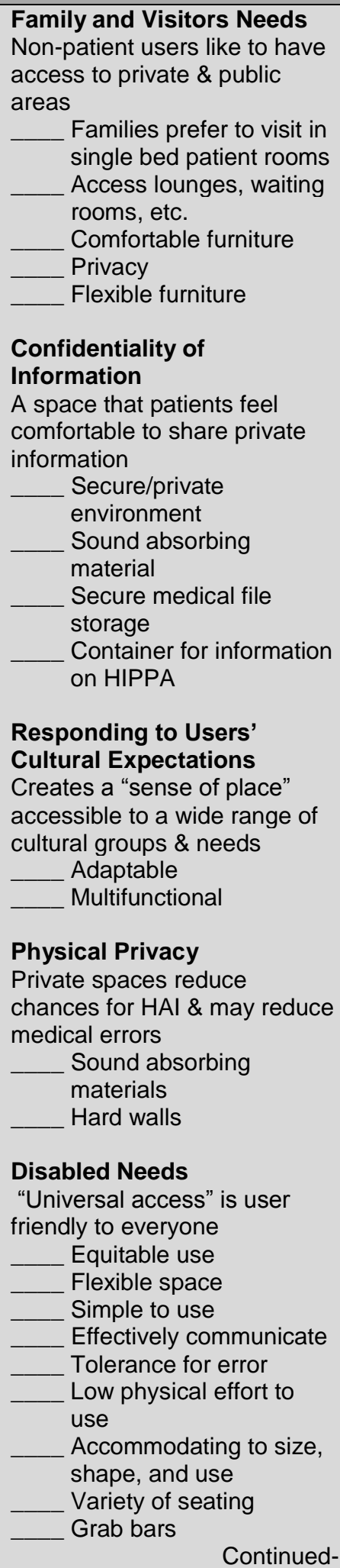 \\
\hline
\end{tabular}




\begin{tabular}{|c|c|c|}
\hline TOPIC & CONCERNS \& CONSIDERATIONS & DESIGN GUIDELINES \\
\hline $\begin{array}{l}\text { User Satisfaction } \\
\text { Issues continued- }\end{array}$ & & $\begin{array}{l}\text { Staff Member Needs } \\
\text { A pleasant environment } \\
\text { reduces stress, anxiety, staff } \\
\text { turnover, \& absenteeism } \\
\text { Access to natural lighting } \\
\text { Bright task lighting } \\
\text { Sound absorbing } \\
\text { materials } \\
\text { Easy access to supplies } \\
\text { Quite workstations } \\
\text { Private patient rooms } \\
\text { Elderly Needs } \\
\text { The environment should } \\
\text { promote independence \& self- } \\
\text { sufficiency } \\
\text { Improved lighting levels } \\
\text { Contrasting material } \\
\text { Sound absorbing } \\
\text { materials } \\
\text { Slip-resistant flooring } \\
\text { Carpeting } \\
\text { Orientation \& Way-finding } \\
\text { Improve efficiency, patient } \\
\text { satisfaction, \& reduces wait } \\
\text { time through design layout and } \\
\text { signage } \\
\text { Radial layout } \\
\text { Clear \& consistent } \\
\text { signage } \\
\text { Minimize single or } \\
\text { double corridors } \\
\text { Communication \& } \\
\text { Information } \\
\text { Privacy improves } \\
\text { communication } \\
\text { Single bed rooms } \\
\text { Sound absorbing } \\
\text { material } \\
\text { Lower lighting levels }\end{array}$ \\
\hline $\begin{array}{l}\text { Accommodating } \\
\text { Change and } \\
\text { Innovation }\end{array}$ & $\begin{array}{l}\text { In order of concern expressed: } \\
\text { Change in medical procedures \& practices, } \\
\text { regulations, program changes from } \\
\text { reimbursement changes, organizational \& medical } \\
\text { culture change, medical technology, and rapid } \\
\text { change in information technology }\end{array}$ & $\begin{array}{l}\text { Change in Medical } \\
\text { Procedures \& Practices } \\
\text { Not Applicable (N/A) } \\
\text { Changes in Regulations } \\
\text { N/A } \\
\text { Program Changes from } \\
\text { Reimbursement Changes } \\
\text { N/A Continued- }\end{array}$ \\
\hline
\end{tabular}




\begin{tabular}{|c|c|c|}
\hline TOPIC & CONCERNS \& CONSIDERATIONS & $\begin{array}{c}\text { DESIGN } \\
\text { GUIDELINES }\end{array}$ \\
\hline $\begin{array}{l}\text { Accommodating } \\
\text { Change and } \\
\text { Innovation } \\
\text { Continued- }\end{array}$ & & $\begin{array}{l}\text { Medical Culture } \\
\text { Change } \\
\text { Adaptable } \\
\text { components } \\
\text { Multifunctional } \\
\text { spaces } \\
\text { Organizational \& } \\
\text { Medical Culture } \\
\text { Change } \\
\text { N/A } \\
\text { Rapid Change in } \\
\text { Information } \\
\text { Technology } \\
\text { Adaptable spaces } \\
\text { Interface ready } \\
\text { hook-ups }\end{array}$ \\
\hline $\begin{array}{l}\text { Environmental } \\
\text { Impact }\end{array}$ & $\begin{array}{l}\text { In order of concern expressed: } \\
\text { Water Management, Solid Waste Management, Toxic } \\
\text { Materials Management, Energy \& Power Management, } \\
\text { Use of Renewable Building Materials, Improving Indoor } \\
\text { Air Quality }\end{array}$ & $\begin{array}{l}\text { Water Management } \\
\text { Water efficient } \\
\text { equipment } \\
\text { Solid Waste } \\
\text { Management } \\
\text { Sharps disposal } \\
\text { boxes } \\
\text { Toxic Materials } \\
\text { Management } \\
\text { Hazardous waste } \\
\text { disposal boxes } \\
\text { Energy \& Power } \\
\text { Management } \\
\text { Energy efficient } \\
\text { equipment } \\
\text { Use of Renewable } \\
\text { Building Materials } \\
\text { Use LEED } \\
\text { certified products } \\
\text { and products with } \\
\text { recycled content } \\
\text { Improving Indoor Air } \\
\text { Quality } \\
\text { HEPA filters } \\
\text { PVC paints } \\
\text { PVC free } \\
\text { materials }\end{array}$ \\
\hline
\end{tabular}

Note. Framework adapted from Critical Issues in Healthcare Environments, by U. Cohen, D. Allison, \& J. Witte, 2009. p. 4. Copyright 2009 by The Center for health Design. 


\section{CHAPTER FIVE: DISCUSSION}

This thesis explores programming for a mobile cancer treatment unit for delivery of services to rural West Virginia. As first fruits of a new interdisciplinary graduate program pairing design process with content from other disciplines across campus, the thesis addressed several overarching goals. The intent was to pair content from a graduate certificate in Healthcare Administration with process from Interior Design. Representatives from both programs served on my committee. My undergraduate degree is in interior design, but my internship and current job were both in hospitals so this was clearly an intersection of personal interest. I anticipate a long and fruitful career in the emerging field of Healthcare Design.

The research was structured to be "translational" in fulfillment of the land grant mission of WVU to serve the people of West Virginia. This choice also speaks to the professional orientation of both the design and medical disciplines. Translational research is defined as research that benefits the population studied through practical, and often commercial, application. With its emphasis on removing barriers to multi-disciplinary collaboration, translational research has been fully embraced by the medical community as a way to move findings "from bench to bedside." The choice of Evidence-based Design as a primary resource also came out of my experience with the medical community, though it is certainly gaining traction among interior designers in the emerging field of healthcare design. 
Initially, I had hoped to do a demonstration project (translational design research using EBD) from start to finish as a model for other design practitioners involved in healthcare related work. Though it would have been wonderful to have a mobile cancer treatment unit under production at this point, it soon became clear that this was an overambitious goal at the master's level. My existing knowledge base, time and money proved significant constraints. The learning curve with regard to medical problems and practice was steep, and very different in culture than my undergraduate major in interior design. This is not a personal excuse, but rather a hard-won and highly-valued insight that healthcare design is clearly a hybrid specialty. Over the past several years, I have found answers to questions that I would never even have thought to ask as a general interior designer. I also found that design and production of a medical environment is expensive and requires participation from a team of experienced experts.

My goals for this thesis became more pragmatic. I would demonstrate the use of EBD in programming as a platform for future practice and further (funded) research. Working with my Committee, I reset the delimitations on this project to include only Phase 1 of the design process. As defined by Kilmer and Kilmer (1992), Phase 1 of the design process is dedicated to analysis. Within these parameters, a designer would commit to the project, state goals and frame expectations, collect relevant data, and analyze that data by sorting into relevant categories and ranking by importance. Thoroughly done, Phase 1 provides a solid, functional foundation for the creative work of Phase 2. The findings in Chapter 4 are my contribution to that foundation. They represent my best attempt to distill current knowledge relevant to this project into a clear, concise, and easy-to-use program for both medical administrators and interior designers. 
More research is clearly required. As a first step I would call for a critical review of my findings by involving all potential stakeholders in focus group and/or survey research to assure that the programming as presented is complete, valid and reliable. I am happy with the start that has been made, but also certain that in this complex and rapidly evolving field there will continue to be substantive revisions with every iteration of critical review.

Additionally, I have come to appreciate the multiple research opportunities relevant to this programming presented by Phase 2 of the design process (see Table 5.1). Broadly, I see opportunity for both creative endeavors and further research across the first two steps of Phase 2 (ideate then choose and refine). The third step (implement and construct) offers similar opportunities for funded research structured either as creative endeavors or qualitative research related to human needs, satisfaction and/or well-being. Such research might be accomplished in partnership with industry, state/local government, or a cause-related non-profit. Funding might also flow from traditional sources in the medical field such as the National Institutes of Health (NIH). The final step (evaluate) is probably best suited for standard survey research, focus groups, appreciative and critical inquiry, photoethnography, and a host of other familiar methods and methodologies. 
Table 5.1.

Further Research Opportunities for Phase 2 of the Design Process

\begin{tabular}{|c|c|c|c|c|}
\hline $\begin{array}{l}\text { Phase 2: } \\
\text { Synthesis }\end{array}$ & Ideate & $\begin{array}{l}\text { Choose \& } \\
\text { Refine }\end{array}$ & $\begin{array}{l}\text { Implement \& } \\
\text { Construct }\end{array}$ & Evaluate \\
\hline Purpose & $\begin{array}{l}\text { Find the } \\
\text { Essence } \\
\text { Formulate } \\
\text { Concepts } \\
\text { Alternate } \\
\text { Options }\end{array}$ & $\begin{array}{l}\text { Possible Choices } \\
\text { Obtain Approval } \\
\text { Decide Best Way } \\
\text { to proceed } \\
\text { Obtain Approval } \\
\text { Obtain Approval }\end{array}$ & $\begin{array}{l}\text { Detail and Specify } \\
\text { Set performance criteria } \\
\text { Assign people/tasks } \\
\text { Put plan into action } \\
\text { Synthesize } \\
\text { Give form to idea } \\
\text { Translate into reality }\end{array}$ & $\begin{array}{l}\text { Appraising } \\
\text { Talking it over } \\
\text { Grading } \\
\text { Criticizing } \\
\text { Future } \\
\text { application }\end{array}$ \\
\hline $\begin{array}{l}\text { Designer's } \\
\text { Terminology }\end{array}$ & $\begin{array}{l}\text { Conceptualize/ } \\
\text { Schematic } \\
\text { Design }\end{array}$ & $\begin{array}{l}\text { Preliminary Design } \\
\text { and Presentation } \\
\text { Design } \\
\text { Development } \\
\text { Final Design and } \\
\text { Presentation }\end{array}$ & $\begin{array}{l}\text { Construction documents } \\
\text { Bidding/negotiating } \\
\text { Selecting contractor } \\
\text { Construction } \\
\text { Occupancy/move-in }\end{array}$ & Follow-up \\
\hline $\begin{array}{l}\text { Project } \\
\text { Development }\end{array}$ & $\begin{array}{l}\text { Schematic } \\
\text { Concepts }\end{array}$ & $\begin{array}{l}\text { Preliminary } \\
\text { Design, Estimates, } \\
\text { Specifications, } \\
\text { Code Check } \\
\text { Revisions/Approval } \\
\text { Design } \\
\text { Development } \\
\text { Costing } \\
\text { Materials Selection } \\
\text { Select Furniture } \\
\text { and Equipment } \\
\text { Outline } \\
\text { Specifications } \\
\text { Consultants } \\
\text { Check Code } \\
\text { Compliance } \\
\text { Client } \\
\text { Review/Approval }\end{array}$ & $\begin{array}{l}\text { Codes check or } \\
\text { approval } \\
\text { Final Cost Estimate } \\
\text { Consultants input } \\
\text { Material selections } \\
\text { Construction documents } \\
\text { including: Working } \\
\text { drawings, } \\
\text { specifications, and } \\
\text { contracts } \\
\text { Contractor's pricing } \\
\text { Client review } \\
\text { Approval of contractor } \\
\text { Revisions } \\
\text { Construction including: } \\
\text { Scheduling, ordering, } \\
\text { supervision/coordination } \\
\text { Installation. } \\
\text { Client move-in } \\
\text { Certificate of } \\
\text { Occupancy }\end{array}$ & $\begin{array}{l}\text { Post } \\
\text { Occupancy } \\
\text { Evaluation } \\
\text { Including: } \\
\text { User input, } \\
\text { client input, } \\
\text { design input } \\
\text { Feedback }\end{array}$ \\
\hline $\begin{array}{l}\text { Methods of } \\
\text { Communication }\end{array}$ & $\begin{array}{l}\text { Bubble } \\
\text { Diagrams } \\
\text { Sketches } \\
\text { Symbols } \\
\text { Written } \\
\text { Information } \\
\text { Conceptual } \\
\text { Models }\end{array}$ & $\begin{array}{l}\text { Formal Drawings } \\
\text { (Orthographic, } \\
\text { Plans, Sections, } \\
\text { Elevations, Details, } \\
\text { Perspectives, } \\
\text { Axonometric) } \\
\text { Finish Models } \\
\text { Verbal Information } \\
\text { Renderings } \\
\text { Presentation } \\
\text { Model }\end{array}$ & $\begin{array}{l}\text { Orthographic drawings, } \\
\text { Plans, elevations, } \\
\text { sections, details, } \\
\text { lighting plan, finish } \\
\text { schedules, mechanical } \\
\text { plans, structural plans, } \\
\text { electrical plans, } \\
\text { specifications, } \\
\text { installation plans, verbal } \\
\text { info, written info, cost } \\
\text { estimates }\end{array}$ & $\begin{array}{l}\text { Interviews } \\
\text { Surveys } \\
\text { Observations }\end{array}$ \\
\hline
\end{tabular}

Note. Adapted from "Designing Interiors," by R. Kilmer and W. O. Kilmer, 1992. p. 158159. Copyright 1992 by Wadsworth Publishing. 
As a final note, I would urge continued contribution to the growing literature in Evidence-based Design. This relatively new initiative is less than a decade in the making. I was surprised at the overall quality and quantity of data that was available, and delighted in the end to find a handful of compilations that made applying those findings easier for practitioners. I would like to thank the Center for Health Design for their support and expansion of the EBD initiative through the "Pebble Project" and through their promotion of EBD through the Healthcare Design journal and the annual Healthcare Design Conference. My hope is that my own modest offering of the findings in Chapter 4 can make a tiny ripple of its own. 


\section{REFERENCES}

Adult Obesity Rankings by State. (2010, July 29). Chicago Tribue. Retrieved April 2, 2011, from http://articles.chicagotribune.com/2010-06-29/health/chi100629obesity-list_1_south-dakota-north-dakota-new-hampshire

American Cancer Society. (2011). Hope Lodge. In Find Support \& Treatment. Retrieved April 5, 2011, from

http://www.cancer.org/Treatment/SupportProgramsServices/HopeLodge/index

American Medical Association. (2011). Patient confidentiality. In Patient Physician Relationship Topics. Retrieved April 21, 2011, from http://www.amaassn.org/ama/pub/physician-resources/legal-topics/patient-physicianrelationship-topics/patient-confidentiality.page

Bánáthy, B. H. (2000). Guided evolution of society: A systems view New York City, NY: Kluwer Academic/Plenum Publishers. Retrieved August 31, 2009, from http://books.google.com/books?hl=en\&lr $=\& \mathrm{id}=\mathrm{rlCZFKYdPQgC \& oi=fnd \& pg=PA} 1 \& \mathrm{dq}=\% 22 \mathrm{~B}$ anathy $\% 22+\% 22$ Guided+evolution+of+societ $\mathrm{y} \% 22+\& \mathrm{ots}=4 \mathrm{tJ} 5 \mathrm{NuJ} 5 \mathrm{~g} \& \mathrm{sig}=\mathrm{jf} 14 \mathrm{vbDpPzq}-\mathrm{D} 0$ 6vjKw nRg9lm0\#v=onepage \&q $=\% 22 \mathrm{Banathy} \% 22$ $\% 20 \% 22$ Guided $\% 20$ evolution $\% 20$ of $\% 20$ society $\% 22 \& \mathrm{f}=$ false

Barlas, D., Sama, A.E., Ward, M.F., \& lesser, M. L. (2001). Comparison of the auditory and visual privacy of emergency department treatment areas with curtains versus those with solid walls. Annals of Emergency Medicine, 38(2), 135-139.

Bass, C. (2009, January 6). Why is black lung back? The Pump Handle. Retrieved January 6, 2009, from http://thepumphandle.wordpress.com/200 9/01/06/why-isblack-lung-back/

Brandis, S. (1999). A collaborative occupational therapy and nursing approach to falls prevention in hospital inpatients. In Journal of Quality in Clinical Practice, 19(4), 215-221. 
Buchanan, T.L., Barker, K.N., Gibson, J. T., Jiang, B. C., \& Pearson, R. E. (1991). Illumination and errors in dispensing. In American Journal of Hospital Pharmacy, 48(10), 2137-2145.

Business Wire. (2001, December 17). US oncology installs mobile PET units to serve east texas and rio grande valley regions of texas. Business Wire. from http://findarticles.com/p/articles/mi $\underline{\text { m0EIN/is_2001_Dec_17/ai_80858419/pg_1?t ag=artBody;col1 }}$

Cancer death rate down for first time. (2008, December 3). Charleston Daily Mail, pp. 12. from http://dailymail.com/News/NationandWor $\underline{\mathrm{ld} / 200811260301 \text { ?page }=2 \& \text { build }=\text { cache }}$

Cancer Research UK. (2008). Why people use complementary or alternative therapies. In CancerHelp UK. Retrieved April 2, 2011, from http://www.cancerhelp.org.uk/about-cancer/treatment/complementaryalternative/about/why-people-use-complementary-or-alternative-therapies\#how

Cancer Treatment Centers of America. (2011, May 1). Explore cancer treatment options. In Care That Never Quits. Retrieved April 2, 2011, from http://www.cancercenter.com/cancertreatments.cfm?source $=$ googlppc\&c $=1089: 1: 2 \&$ ef $i d=1812: 3:$ s $5 \mathrm{c} 1 \mathrm{ac} 1 \mathrm{a} 6 \mathrm{~b} 7 \mathrm{~d} 86$ d4317e9b82ddffab95b_831410725:FqokXdBkLCYAAFfBwMUAAAAX:20081 $\underline{206194915}$

Cancer Treatment Centers of America. (2008) Explore cancer treatment options at CTCA. Retrieved December 6, 2008, from http://www.cancercenter.com/cancertre atments.cfm?source $=$ googlppc $\& \mathrm{c}=1089: 1: 2 \&$ ef_id=1812:3:s 5c1ac1a6b7d86d4317e9b82d dffab95b_831410725:FqokXdBkLCYAAFfBwMUA AAAX:20081206194915

Carpenter, M. (2009, April 26). The new children's hospital: Design elements combine to put patients, parents at ease.Pittsburgh Post-Gazette. Retrieved April 15, 2011, from http://www.post-gazette.com/pg/09116/965608-114.stm

Carpman, J. R., \& Grant, M. A. (1993). Design that cares: Planning health facilities for patients and visitors ( $2^{\text {nd }}$ ed.). Chicago: American Hospital Publishing, Inc. 
Cedars-Sinai. (2011). About cedars-sinai. In Cedars-Sinai. Retrieved April 2, 2011, from http://www.cedars-sinai.edu/About-Us/

Chang, J.T., Morton, S. C., Rubenstein, L. Z., \& Majica, W.A. (2004). Interventions for the prevention of falls in older adults: Systematic review and meta-analysis of randomized clinical trials. In British Medical Journal. 328(7441), 680.

Chaudhury, H., Mahmood, A., \& Valente, M. (2003). Pilot study on comparative assessment of patient care issues in single and multiple occupancy rooms. Unpublished report: the Coalition for Health Environments Research.

Cohen, U., Allison, D., \& Witte, J. (2009). Critical issues in healthcare environments. The Center for Health Design.

Cole, B. West virginia state map collection. Geology.com, 2008. Retrieved February 2, 2009, from http://geology.com/state-map/west-virg inia.shtml

Cross, N. (1982). Designerly Ways of Knowing (Vol. 3, pp. 221-227). , Germany: Springer - Verlag.

Dijkstra, K., Pieterse, M., \& Pruyn, A. (2006, July 25). Physical environmental stimuli that turn healthcare facilities into healing environments through psychologically mediated effects: Systematic review. Journal of Advanced Nursing, 56(2), 166181.

Diette, G. B., Lechtzin, N., Haponik, E., Devrotes, A. \& Rubin, H. R. (2003). Distraction therapy with nature sights and sounds reduces pain during flexible bronchoscopy: A complementary approach to routine analgesia. In Chest, 123(3), 941-948.

Edwards Comprehensive Cancer Center. (2009, January 15). Hope close to home. In You'll Find Hope Here. Retrieved April 2, 2011, from http://edwardsccc.org/home/

Eggen, H. (2008, October 14). Culture for healthcare architecture. Healthcare Design Magazine. Retrieved April 19, 2011, from http://www.healthcaredesignmagazine.com/ME2/dirmod.asp?sid=\&nm=\&type= Publishing\&mod=Publications\%3A\%3AArticle \&mid $=8$ F3A7027421841978F18 BE895F87F791\&tier=4\&id=B9ADCAA0224E4C8FB79C7FA7C7FBD884 
Ehealth MD. (2008). What is radiation therapy? Retrieved December 19, 2008, from http://www.ehealthmd.com/library/radia tiontherapy/RT_whatis.html

Eisen, S. (2006). Effects of art in pediatric healthcare. Unpublished doctoral dissertation. Texas A\&M University, College Station, TX: Department of Architure.

Engli, M., \& Kirsivali-Farmer, K. (1993). Needs of family members of critically ill patients with and without acute brain injury. The Journal of Neuroscience Nursing: Journal of The American Association of Neuroscience Nurses, 25(2), 78-85.

Fairmont General Hospital (2009). Services available in outpatient oncology area;. oncology. Retrieved March 6, 2009, from https://www.fghi.com/PtPortal/Services Programs/tabid/53/ctl/Edit/mid/572/ /Se rvicesPrograms/Oncology/tabid/116/Defau lt.aspx?PageContentID=194

Farber Specialty Vehicles. (2011). In Mobile Medical. Retrieved April 26, 2011, from http://www.fsvcc.com/medical/

Flynn, E. A., Barker, K. N., Gibson, J. T., Pearson, R. E., Berger, B. A., \& Smith, L. A. (1999). Impact of interruptions and distractions on dispensing errors in an ambulatory care pharmacy. In American Journal of Health Systems Pharmacy, 56(13), 1319-1325.

Get Directions. (2011, April 2). In Map Quest. Retrieved April 2, 2011, from http://mapq.st/enKt2t

Goins, T. R. \& Krout, J. A. (Eds.). (2006). Service delivery to rural older adults: research, policy, and practice. 11 West 42nd St., New York, NY 10036: Springer Publishing Company, Inc.

Gulwadi, G. B., \& Calkins, M. P. (2008, July 1). Impact of healthcare environmental design on patient falls. In The Center for Health Design. Retrieved April 13, 2011, from http://www.healthdesign.org/chd/research/impact-healthcareenvironmental-design-patient-falls

Harris, D. (2000). Environmental quality and healing environments: A study of flooring materials in a healthcare telemetry unit. Unpublished Doctoral Dissertation, Department of Architecture, Texas A\&M University, College Station, TX. 
Harris, P. B., McBride, G., Ross, C., \& Curtis, L. (2002). A place to heal: Environmental source $\mathrm{s}$ of satisfaction among hospital patients. Journal of Applied Social psychology, 32 (6), 1276-1299.

Heskett, J. (1997). Toothpicks and logos: Design in everyday life (p. 7). New York, NY: Oxford University Press. Retrieved April 3, 2011, from http://www.amazon.com/Toothpicks-Logos-Design-EverydayLife/dp/0192804448\#reader_0192804448

Healthwise. (2008, May 8). Black lung disease-topic overview. In Lung Disease \& Respiratory Health Center. Retrieved April 2, 2011, from http://www.webmd.com/lung/tc/black-lung-disease-topic-overview

Hewitt, M. E., Ganz, P. A. \& Hewitt, M. (2007). Implementing cancer survivorship care planning. National Academies. Retrieved September 2, 2008, from http://www.google.com/books?id=46Z_mnk JRAQC

Holahan, C. (1972). Seating patterns and patient behavior in an experimental dayroom. Journal of Abnormal Psychology, 80 (2), 115-124.

Hope For Tomorrow. (2010, July 8). Mobile chemotherapy unit project. In Hope For Tomorrow. Retrieved April 3, 2011, from http://www.arttogive.co.uk/mobile_chemotherapy_unit

Hott, K. (2010, October 14). Lifecare medical transports committed to a cause [Television broadcast]. Charollettesville: NBC29 WVIR-TV. Retrieved October 18, 2010, from http://www.nbc29.com/story/13325128/lifecare-medicaltransports-committed-to-a-cause

How Stuff Works. (2011). In Geography of West Virginia. Retrieved April 2, 2011, from http://geography.howstuffworks.com/united-states/geography-of-westvirginia.htm

Intercultural Cancer Council. Rural poor and the medically underserved and cancer. Intercultural Cancer Council Network. Retrieved March 24, 2009, from http://iccnetwork.org/cancerfacts/ICC-CFS6.pdf 
Joint Commission on Accreditation of Healthcare Organiations. (2009, January). Universal design for health care facilities: Addressing safety, access to care for a diverse patient population. Environment of Care News, 12(1), pp. 8, 11. Retrieved April 21, 2011, from http://thebarrierfreehealthcareinitiative.org/wpcontent/uploads/2009/06/universal-design-for-health-care-facilities-1.pdf

Kanzius, J. (2007, Oct, 14). "PCN profiles-john lanzius." PCN Profiles. In By Bova Bill. Erie, Pennsylvania: PCN.

Kanzius, J. (2008, Dec, 19). "Non-invasive targeted radio-frequency cancer treatment." The Early Show. In By Benno Schmidt. Erie, PA: CBS News.

Kaunonen, M., Tarkka, M. T., Paunonen, M., \& Laippala, P. (1999). Grief and social support after the death of a spouse. Journal of Advanced Nursing, 30(6), 13041311.

Kilmer, R., \& Kilmer, W. O. (1992). Designing Interiors (p. 156). Beverly, MA: Wadsworth Publishing.

Kistner, U. A., Keith, M. R., Sergeant, K. A., \& Hokanson, J. A. (1994). Accuracy of Dispensing in a High-Volume, Hospital-Based Outpatient Pharmacy. In American Journal of Hospital Pharmacy. 51(22), 2793-2797

Koivula, M., Tarkka, M. T., Tarkk, M., Laippala, P., \& Paunonenilmonen, M. (2002). Fear and in-hospital social support for coronary artery bypass grafting patients on the day before surgery. International Journal of Nursing Studies, 39(4), 415-427.

Laitinen, P., \& Isola, A. (1996). Promoting participation of informal caregivers in the hospital care of the elderly patient: Informal caregivers' perceptions. Journal of Advanced Nursing, 23(5), 942-947.

Lankford, M. G., Collins, S., Youngberg, L., Rooney, D. M., Warre, J. R., \& Noskin, G. A. (2006). Assessment of materials commonly utilized in health care: Implications for bacterial survival and transmission. In American Journal of Infection Control. 34(5), 258-263.

Leather, P., Beale, D., Santos, A., Watts, J., \& lee, L. (2003). Outcomes of environmental appraisal of different hospital waiting areas. Environment \& behavior, 35(6), 842-869. 
LifeLineMobile. (2011). Gallery. In LifeLineMobile. Retrieved April 26, 2011, from http://www.lifelinemobile.com/gallery1.htm

Malenbaum, S., Keefe, F. J., Williams, A. C., Ulrich, R., \& Somers, T. J. (2008). Pain in its environmental context: Implications for designing environments to enhance pain control. In Pain. 134, 241-244.

Mary Babb Randolph Cancer Center. (2011). Bonnie's bus - mobile mammography program. In Mary Babb Randolph Cancer Center at West Virginia University. Retrieved April 3, 2011, from http://wvucancer.org/bonnie

Mathis, M. (1984). Personal needs of family members of critically ill patients with and without acute brain injury. Journal of Neurosurgical Nursing, 16(1), 36-44.

Mayo Clinic. (2008). Chemotherapy: drug treatment uses chemicals to kill cancer cells. MayoClinic.com. Retrieved December 19, 2008, from http://www.mayoclinic.com/health/chemo therapy/CA00029

McMurray, D. I. (1998). Psychological, social, and medical factors affecting rehabilitation following coronary bypass surger. Journal of Rehabilitation, 64(1), 14-18.

Medical Coaches. (2004). Mobile Health/Medical Units. In Startracks.org: Portable Site for Startracks Technology. Retrieved April 26, 2011, from http://www.startracks.org/

Medical Coaches. (2008). Mobile Health/Medical Units. In Mobile Medical Vehicles Custom Design \& Built. Retrieved April 26, 2011, from http://www.medicalcoaches.com/products/clinic/

Melin, L., \& Gotestam, K. G. (1981). The effects of rearranging ward routines on communication and eating behaviors of psychogeriatric patients. Journal of Applied Behavior Analysis, 14(1), 47-51.

Merriam-Webster. (2011a). "Adapt" Definition. In Marriam-Webster Dictionary. Retrieved April 21, 2011, from http://www.merriamwebster.com/dictionary/adapt 
Merriam-Webster. (2011b). “Commit” Definition. In Merriam-Webster Dictionary.

Retrieved April 8, 2011, from http://www.merriam-

webster.com/dictionary/commit

Merriam-Webster. (2011c). "Sustainable" Definition. In Marriam-Webster Dictionary. Retrieved April 21, 2011, from http://www.merriamwebster.com/dictionary/sustainable

Miller, A. C., Hickman, L. C., \& Lemasters, G. K. (1992). A destruction technique for control of burn pain. In Jounal of Burn Care and Rehabilitation. 13(5), 576-580.

Miller, K. (June 2006). Demographic and economic profile of west virginia. RUPRI (Rural Policy Research Institute), 1-17. Retrieved December 4, 2008, from http://www.rupri.org/Forms/WestVirgini a.pdf

Mobile Specialty Vehicles. (2010, March 27). Mammography. In Mobile Mammography: MSVGlobal. Retrieved April 26, 2011, from http://msvglobal.com/content/?cat=12

Molter, N. C. (1979). Needs of relatives of critically ill patients: A descriptive study. Heart and Lung: The Journal of critical Care, 8(2), 332-339.

National Cancer Institution. (2004, March 16). Obesity and cancer : Question and answer. In National Cancer Institution. Retrieved April 2, 2011, from http://www.cancer.gov/cancertopics/factsheet/Risk/obesity

Peterson, R., Knapp, T., \& Rosen, J. (1977). The effects of furniture arrangement on the behavior of geriatric patients. Behavior Therapy, 8, 464-467.

Pierce, R. A., $2^{\text {nd }}$, Roger, E. M., Sharp, M. H., \& Musulin, M. (1990). Outpatient pharmacy redesign to improve work flow waiting time, and patient satisfaction. American Journal of Hospital Pharmacy, 47(2), 351-356.

Press Ganey, Inc (2007). Hospital pulse report: Patient perspectives on American healthcare. Retrieved April 26, 2011, from http://www.pressganey.com/galleries/default-file/hospital-report.pdf 
Posada, M. M. (n.d.). Ergonomics for the aging population: Implementing methods to maintain quality of life. In Human Factors and Ergonomics Society . Retrieved April 26, 2011, from

http://hfesnem.org/articles_files/Ergonomics_for_the_aging_population.pdf

Sallstrom, C., Sandman, P. O., \& Norber, A. (1987). Relatives' experience of the terminal care of long-term geriatric patients in open-plan rooms. Scandinavian Journal of Caring science,1(3-4), 133-140.

Shakopee Mdewakanton Sioux Community. (2009). Multi-functional mobile medical unit fact sheet. In Newsroom. Retrieved April 8, 2011, from http://www.shakopeedakota.org/newsroom/fact-sheets/multi-functional-mobilemedical-unit-fact-sheet

Shepley, M. M., \& Davies, K. (2003). Nursing unit configuration and its relationship to noise and nurse walking behavior: An AIDS/HIV unit case study. AIA Academy Journal. Retrieved April 26, 2011, from http://www.aia.org/aah/journal/0401/article4.asp

Sommer, R., \& Ross, H. (1958). Social interaction on a geriatrics ward. The Internation Journal of Social Psychiatry, 4(2), 128-133.

State of West Virginia. (2011). In West Virginia: Department of Transportation. Retrieved April 2, 2011, from http://www.transportation.wv.gov/Pages/default.aspx

Stoneking, S. (2008) Cancer physicians form west virginia oncology society. Healthcare at West Virginia University. Retrieved January 21, 2009, from http://www.health.wvu.edu/newsreleases /news-details.aspx?ID=927

Summary of Proposed Rule on Designation of Medically Underserved Populations and Health Professional Shortage Areas: 73 Fed. Reg. 11232. (2008, February 29). In NATIONAL ASSOCIATION OF COMMUNITY HEALTH CENTERS (NACHC). Retrieved February 4, 2009, from http://www.nachc.org/client/documents/summary_of_shortage_designation_prop osed_rule_-_03_10_08.pdf 
Surrenti, S. (2009). Hospital Design and Cultural Diversity. Retrieved April 19, 2011, from http://www.cityfutures2009.com/PDF/6_Surrenti_Silvia.pdf

Tarkka, M. T., Paavilainen, E., Lehti, K., \& Astedt-Kurki, P. (2003). In-hospital social support for families of heart patients. Journal of Clinical Nursing, 12(5), 736743.

The Center for Health Design. (2010) The Center for Health Design. The pebble project overview. Retrieved March 23, 2010, from http://archived.healthdesign.org/research/pebble/overview.php

The Center for Health Design. (2011). In Resources. Retrieved April 4, 2011, from http://archived.healthdesign.org/resources/

Tobacco. (2009, March). In WCWV. Retrieved April 2, 2011, from https://www.pwc123.com/web/wcwv/tobacco

Ulrich, R. S., Lunden, O., \& Eltinge, J. L. (1993). Effects of exposure to nature and abstract pictures on patients recovering from heart surgery. Paper presented at the thirty-third meeting of the Society for Psychophysiological Research. In Psychophysiology. 30, 7.

Ulrich, R. S., Zimring, C., Zhu, X., Dubose, J., Seo, H., Choi, Y., Quan, X., \& Joseph, A. (2008, September). Review of the research literature on evidence-based healthcare design. In The Center for Health Design. Retrieved April 13, 2011

University of Pittsburgh Medical Center [UPMC]. (2011). Building for the future. In Children's Hospital of Pittsburgh of UPMC. Retrieved April 15, 2011, from http://www.cc-peds.net/nursing/prideBuilding.php

U.S. Bureau of Labor Statistics. (2010). Databases, Tables \& Calculators by Subject. Retrieved October 25, 2010, from http://data.bls.gov/PDQ/servlet/SurveyOutputServlet?data_tool=latest_numbers\& $\underline{\text { series_id=LASST54000003 }}$

U.S. Census Bureau. (2010). West Virginia. In State \& County Quick Facts. Retrieved April 2, 2011, from http://quickfacts.census.gov/qfd/states/54000.html 
U.S. Census Bureau. "United states census 2000." Census 2000 Data for the State of West Virginia. May 7, 2003. Retrieved January 23, 2009, from http://www.census.gov/census2000/state s/wv.html

Verhaegh, S., Defloor, T., Van Zuuren, F., Duijnstee, M., \& Grypdonck, M. (2005). The needs and experiences of family members of adult patients in an intensive care unit: A review of the literature. Journal of Clinical Nursing, 14(4), 501-509.

Vendome Group, LLC. (2008, August). Textiles/Fabrics, Solid Surfaces, Flooring. In http://www.healthcaredesignmagazine.com/ME2/dirmod.asp?sid=9B6FFC446 FF7486981EA3C0C3CCE4943\&nm=Articles\&type=Publishing \&mod=Publicati ons\%3A\%3AArticle\&mid=8F3A7027421841978F18BE895F87F791\&tier $=4 \&$ id $=8 \mathrm{CF}$. Retrieved April 26, 2011, from http://www.healthcaredesignmagazine.com/ME2/dirmod.asp?sid=9B6FFC446FF 7486981EA3C0C3CCE4943\&nm=Articles\&type=Publishing \&mod=Publication s\%3A\%3AArticle\&mid=8F3A7027421841978F18BE895F87F791\&tier $=4 \&$ id $=8$ $\mathrm{CF}$

West Virginia Very Small Towns and Villages (fewer than 1000 residents). (2009). In City-Data.com. Retrieved April 2, 2011, from http://www.citydata.com/city/West-Virginia3.html

West Virginia Department of Health and Human Resources. (2008). West virginia medically underserved areas (MUAs) West Virginia Department of Health and Human Resources, October 2008. Retrieved January 16, 2009, from http://www.wvochs.org/shared/content/r ecruitment/08mua1008.pdf

Wilmott, M. (1986). The effect of a vinyl floor surface and carpeted floor surface upon walking in dlderly hospital inpatients. Age and Aging, 15(2), 119-120. Retrieved April 26, 2011, from http://ageing.oxfordjournals.org/content/15/2/119.abstract

WVU Healthcare. (2006, June 19). Quickfacts. In General Information. Retrieved April 3, 2011, from http://wvuhealthcare.com/general/quickfacts/hscemployment.aspx

Zeidler, E. H. (2005). Hospital design for emotional and cultural needs. In Design and Health. Retrieved April 21, 2011, from www.designandhealth.com/uploaded/documents/publications/papers/eh-zeidlerWCDH-2005.pdf 